\title{
Generational Communities: Student Activism and the Politics of Becoming in South Asia
}

Jean-Thomas Martelli and Kristina Garalytė

\section{(2) OpenEdition}

Electronic version

URL: http://journals.openedition.org/samaj/6486

DOI: $10.4000 /$ samaj.6486

ISSN: $1960-6060$

Publisher

Association pour la recherche sur l'Asie du Sud (ARAS)

\section{Electronic reference}

Jean-Thomas Martelli and Kristina Garalyte, "Generational Communities: Student Activism and the Politics of Becoming in South Asia », South Asia Multidisciplinary Academic Journal [Online], 22 | 2019, Online since 21 April 2020, connection on 05 August 2020. URL : http://journals.openedition.org/ samaj/6486

This text was automatically generated on 5 August 2020

\section{$(\mathbb{1 0 \Theta \Theta}$}

This work is licensed under a Creative Commons Attribution-NonCommercial-NoDerivatives 4.0 International License. 


\title{
Generational Communities: Student Activism and the Politics of Becoming in South Asia
}

\author{
Jean-Thomas Martelli and Kristina Garalytè
}

1 The wide resonance of the aphorism, "from shadows to the stars," closing the 2016 suicide letter of lower caste student activist Rohith Vemula ${ }^{1}$ suggests broken hopes for South Asian educated youth. It points at the tragic obstacles to political change and social upliftment experienced by many young people, reflecting a characteristic desire for individual and collective change. The astounding protests that ensued from Rohith's suicide in India are now contributing to the revival of scholarly interest in the formation of political attitudes among educated youth, subjecting the question of students' socialization into politics to academic scrutiny. Indeed, amidst the uncertain social, economic and political promises of the South Asian educational bulge, ${ }^{2}$ contemporary politics in university spaces in South Asia has the potential of shaping youth as idiosyncratic generations. They are characterized not only by their aspirations for a better future, but also by their ability to experience collectively, yet in their own way, major political and social events.

2 Making sense of this research agenda revival is core to this special issue's enquiry, which runs through ethnographic and historical insights of eight contributions, covering youths' experiments with politics in Bangladesh, India and Pakistan. This introduction questions the relevance of student politics as an object of inquiry by asking whether it truly constitutes a field that is autonomous from wider organized politics. By interpreting student politics as political becoming, this collection of articles indicates that everyday campus-based activism is a potent vehicle for the (re)production of contemporary South Asian polity. Interrogations over the meaning of this "(re)"sprinkle the issue, as authors debate how student politics, understood as an experimental learning process of politics within a given educational space (Loader, Vromen and Xenos 2014) both produces and reproduces political imaginaries, cultural tropes and social hierarchies. While party politics is not always central in the conduct 
of student politics in South Asia, its socializing presence in campuses-especially for non-elite sections of the student population-stands out when compared to less structured student mobilizations in Western counterparts (Muxel 2011, 2018). Through introducing the articles of this issue, we are interested in mapping the poorly charted territory of politics among generational communities in university spaces in South Asia. Here our understanding of community entails three criteria: social ties connecting those who are part of the university environment; a physical or virtual proximity between its members; and a set of meaningful interactions that serve as collective binder (Kusenbach 2006; Schafer 2019).

Our concept of generational communities applies first and foremost, if not only, to youth communities, since the identification of individuals to a perceived and situated age group is rarely strong enough to form communities on that basis in other cases. Consequently, generational communities are in our understanding partly ascriptive, partly self-selected communities in which a set of networked and youthful cohorts are engaged, directly or indirectly with formal or informal education. Their distinctiveness lies in their production at the micro-level of shared thinking, self-fashioning and of framing perspectives and grids of understandings, as well as formative engagements with macro socio-political turns. Contrary to student communities which necessarily have administrative and academic existence, generational communities can be more inclusive, fluid, relational, processual, dynamic and eventful (Brubaker 2004). They may include non-students, teachers, alumni, peers, relatives contributing to educational life, friendships and more formal organizational linkages, as well as neighborhood ecologies, infrastructure businesses, coaching agencies, vocational training centers or placement structures tied to the educational field, NGOs and political organizations, cadres and leaders supporting student politics. The territorial boundaries of a generational community are not always overlapping with campus boundaries. Politics involving decisive inputs of students can happen outside university premises. Educated youth politics online is rarely restricted to batchmate-only discussion groups; networks of student activists entail both campus and non-campus territories, include university neighborhoods, nonresidential educational spaces, work and leisure nexuses, distant and part-time education. Thus, the scale of generational communities is not youth at large, but more granular and internally heterogeneous assemblages of youthful individuals engaged in group-making and generating political readings and events. As generational communities produce "situated actions, cultural idioms, cognitive schemas, discursive frames, organizational routines, institutional forms, political projects, and contingent events" (Brubaker 2004:11), their perimeter of action can vary significantly, depending on parameters such as degrees of socialization, cultures of public participation, interconnectedness between educational spaces and wider geographies. Generational communities tend to survive the university years, albeit to varying degrees, orienting friendships, cognitive frames and political orientations, but also professional, family and other life choices of ex-students. Depending in part on levels of socialization and public engagement of individuals during university years, they continue to engage with their former educational setting, participating in alumni meetings, mentoring and counselling student activists, teaching new batches of students or simply loitering in campus spaces. The "prestige" and/or "stigma" of one's participation in certain generational communities sometimes accompany individuals long after student years, orienting the way relatives, friends, colleagues and the general public introduce and perceive them. Hence, for many years a "passed out" 
(graduated) student activist can be referred to as "JNUite" (i.e. someone who has attended Jawaharlal Nehru University-JNU) or former UoHSU office bearer (i.e. member of the Students' Union of the University of Hyderabad-UoH).

Working out an operational typology we suggest that student politics in South Asia navigates in between two ideal-types of generational communities. Building on both the contributions of this issue and the existing literature, our first ideal type understands the campus as a natural community, whose engagement with politics is mainly defined by its location in the socio-political space, being primarily structured around class, caste, gender, religion, economic aspirations, social upbringing and muscle politics (Lukose 2011; Jeffrey and Young 2013; Ruud 2014; Kuttig 2019). The second approach considers that what is to be represented in student activism is a political community in which, through ideational and agonistic politics, social lines of fracture are addressed, imagined, tilted and at times subverted. Whereas natural communities are primarily in-situ cohorts of networked individuals of similar age aligned with the broader socio-political context in which they thrive, political communities are also characterized by their ability to be politicized differentially through inter-cohort emulation, carrying the potential to emerge as autonomous counter publics (Warner 2002), showing degrees of collective volitional agency, selforganization and sovereignty. As a result, natural communities tend to emphasize student-specific concerns while being tributaries of the wider political field. Political communities rather converse with it, fueling debates and reconfiguring regional and national contentions (Gautier 2020). To sum up, natural communities tend to reproduce capital, morality, hierarchies and zeitgeists among students, while political communities tend to renegotiate such constructs-with more or less success (Nisbett 2007).

5 By bringing the ideational work of student activists back to the center of the academic discussion, this special issue does not attempt to prioritize ideology over other forms and aspects of student politics. In line with recent work on political youth engagement within the Global South (Oinas, Onodera and Suurpää 2017; Snellinger 2018), we aim at a more nuanced and balanced understanding of the interplay between pragmatic and idealistic motives within student political activism in South Asia. We highlight the contradictory nature of student political activism, as students seek "political opportunity within the framework of a revolution" (Snellinger2018:3). Oinas and colleagues (2017) remind us that it is important not to get "trapped in either/or polarizing analysis" and to acknowledge that student political engagement can be "simultaneously self-interested, pragmatic and utopian" (Oinas, Onodera and Suurpää 2017:12). In a shift away from reductionist, idealizing or denigrating approaches, contributions of this special issue place individuals and their collective agency within larger socio-political contexts that structure students' engagement with the political.

6 In line with others (e.g. Snellinger 2018), we suggest that various streams of student activism have in common a vision of the campus as a springboard for securing symbolic, social and economic gains, often in articulation with the need to provide support for political parties, notably through identifying new cadres and incipient leadership (Hazary 1987). We indicate however that such a perspective alone does not entirely explain the specificity as well as the variability of the phenomena under study. It does not reflect either on the way student politics is enabled and enmeshed in 
biographical reconfiguration, nor on the conditions that nurture it. Complementing studies that outline the long-term individual consequences of political activism (McAdam 1988; Della Porta 2019; Fillieule and Neveu 2019) we suggest that student activism itself is characterized by individual and collective self-change, understood as a set of everyday intimate experiences and instrumental performances. Because of the trial-and-error aspect of students' engagements with politics, we locate their distinctiveness in the way activists undergo and display self-change as a form of political becoming. We further locate political outcomes of these transformative processes within a generation that is youthful constituencies experiencing differentially social transformations and impactful political events in an identifiable sociocultural location (Mannheim [1928]1952). While advertisements of the self are a defining feature of student politics and do index claims to political representation (Martelli 2019b), their relevance depends on their target "audience," that is, the student community in which representation claims are enshrined. Two popular modalities of youth selffashioning emerge as politically successful. One is based on displays of generosity, service and charismatic strength to ensure responsiveness to the downtrodden and one's community (Snellinger 2018; Michelutti et al. 2019; Koskimaki 2020); the other is rooted in signs of forfeiting or asserting one's social status to ensure representation of the downtrodden and one's community while powering student agitations (Martelli 2019b). Thus, student politics is characterized by the injunction to craft coherent narratives of the self (Naudet 2011) both morally acceptable and politically successful, for example through giving back (Garalyte 2020) or netaizing (i.e. embodying the ethos of the neta, the political leader).

7 This issue aims at mobilizing the notion of generational communities in order to address the relevance and the specificity of student politics in South Asia. How distinctive is student politics from mainstream political participation and what relationships do they entertain? What is the role of generations in renewing political participation? What are the sets of individual and collective practices and performances that enable to represent youth in contemporary South Asia? What is the role of campuses as spaces of political incubation? What are the regional specificities of student politics? To which extent the sociological and academic composition of the campus orient the political ideas and material demands produced on campus? While we go on engaging with the geographical and sociological plurality of campus activism in South Asia, we propose the aforementioned functional typology as an effective navigational compass enabling inter- and intra- regional comparisons, while facilitating comparative entry points with global scenarios. In the following four sections, we review the substantial variability of the phenomenon under study before categorizing the way student politics is portrayed in anthropological youth studies and more widely in relevant political science, sociology and historical fields. Prior to introducing the eight articles of the issue, we make a case for the study of educated youth self-fashioning from the lens of generational communities.

\section{Fragmented Collectives: The Many Fault Lines of Student Activism in South Asia}

8 Student political activism is a significant extra-curricular activity for students in university spaces, along with-and sometimes in lieu of-fraternities, publication clubs, 
religious groups, athletic teams and cultural organizations (Altbach 2006). Oppositional in nature, but not necessarily anti-establishment, the drawing of the contours of student activism in South Asia is hampered by a strong contextual modularity. We identify five overlapping parameters instrumental in shaping the character, magnitude and terrain of student politics in South Asia: academic environment, student composition, cultural and ideological legacies, public/private arrangements and finally regional historical dynamics in engaging with state and non-state actors.

From a structural point of view, the emergence of student politics always depends on the educational context. The underlying assumption in social movement theory is that the university-based social networks (Crossley 2008) as well as the absence of personal constraints to collective action in given territories (i.e. "biographical availability," McAdam 2013) are conducive to making new generations join a broad range of contentious politics (Della Porta 2019). Biographical availability is indubitably higher in older public institutions than newer for-profit educational structures (Altbach 2006). ${ }^{3}$ In the former settings, traditional student cultures often offer the possibility of new political socializations (Fillieule 2013) before and after classes, thus "interrupting the flow of habits" (Schutz 1976) of primary socializations acquired from parental upbringing. However, the distinction between private and public institutions is blurred in places where formal higher education is highly dysfunctional, and where student politicization necessitates uncertain time investments (e.g. "timepass," Jeffrey 2010; "time-use," Andersen 2016), loitering (Lukose 2009), flirtation (Osella and Osella 1998) and male-centric leisure (Verkaaik 2004). In contrast, in more prestigious sites of higher education, students' engagements with politics are tied up with personal experiences of upward social mobility (Garalyte 2020; Fernandez 2018).

Due both to strong endogenous political traditions and a certain degree of selfselection, studies on student movements in various countries acknowledge the leading political role taken by prestigious universities in the social sciences (Altbach [1991]2014; Luescher and Mamashela 2015). Globally the picture seems to hold true: Zhao (2004) finds that among people involved in the 1989 Tiananmen Square movement in China, students from the social sciences and humanities were overrepresented-for instance, of the 21 most-wanted student leaders of the 1989 movement, 14 majored in those areas. Ketchley and Biggs (2016) along with Gambetta and Hertog (2016) find that Islamist political activism after the 2013 military coup in Egypt was imbued by university students and graduates from prestigious institutions. However, the South Asian scenario only partly conforms to the larger picture. Early phases of Maoism in India (Banerjee 1984) relied on science students, while Nepali Maoism was more often carried out by students with sociology and political science majors (Snellinger 2010). While some emphasize that a handful of prestigious institutions in South Asia continue to harbor key value-based student movements (Altbach 2006; Martelli and Parkar 2018), others have outlined the importance of "provincial" educational institutions in deepening social movements (Pathania 2018). For instance, the 1974 "JP movement," protesting against corruption and the doubling price of food grain in Bihar (India) was led by students of provincial universities of the state (Carrasco 2013). Similarly, 1968 protests in East-Pakistan emerged in the context of the massification of higher education and the increase of new non-elite colleges affiliated to older universities (Raghavan 2013). 
11 As for the academic context, the social composition of students in educational settings is instrumental in shaping their political attitudes. South Asian youth from lower economic backgrounds are, when compared to more affluent youth globally, on average more involved in electoral politics, in particular when it comes to casting their vote (Jaffrelot and Van der Veer 2008; Kumar 2019). Standing against all-encompassing processes of the "creolization" of democracy (Yadav 1999), youth upper castes and classes are, like elder "privileged" cohorts characterized by their escapism in the face of the triumph of plebeian's politics. Figure 1 below, summarizing key findings of a student survey in a pan-Indian university (Jawaharlal Nehru University, JNU) (Martelli and Ari 2018) confirms to an extent existing social biases towards political participation. It shows that social biases on campus are further differentiated according to students' political affiliations, thus reinforcing the idea that the campus constitutes a cohesive political field. Such differences proxy the fact that group representation by specific student organizations is not entirely different than what is practiced by their parental organization(s) outside university spaces, even if JNU student politics displays comparatively higher levels of social inclusiveness (Martelli and Parkar 2018). All in all, the transformations of South Asian democracies, and in particular their vernacularization (Michelutti 2008), are shared by campuses and wider dwelling spaces alike, irrespective of whether their political attributes point to political violence in Bangladesh (Bal and Siraj 2017; Suykens 2018) or Islamic identity in Pakistan (Nelson 2011). 
Figure 1: Social Space of Student Activists in Jawaharlal Nehru University According to their Student Organization

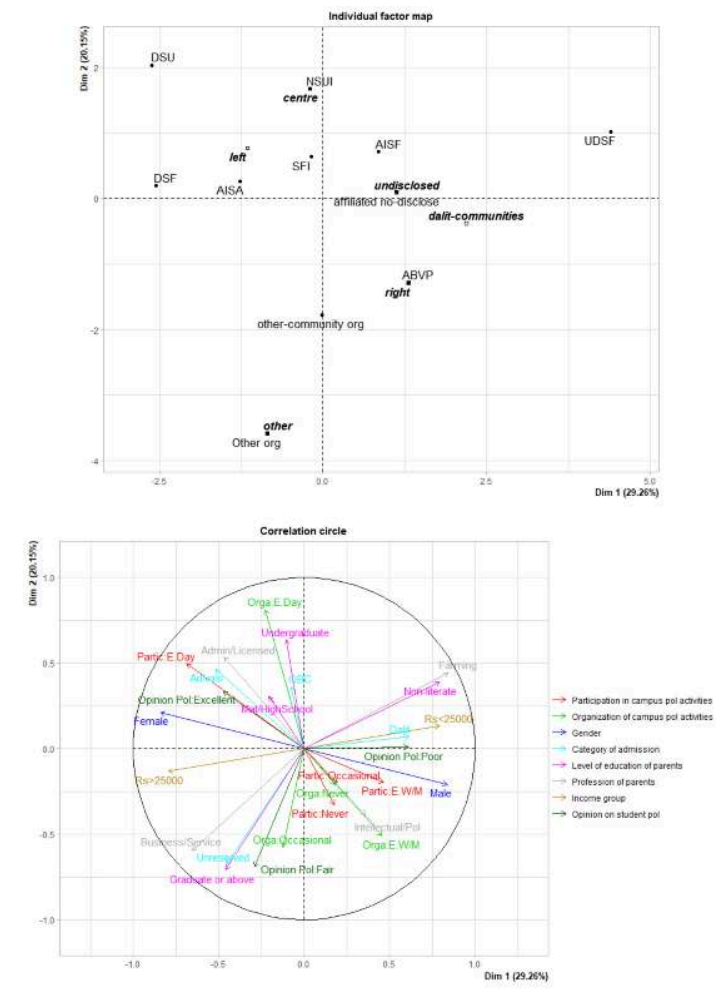

In the correlation circle, "Orga:E.Day" stands for "organization of political events every day." Similarly, "Partic:E.W/M" means"political participation every week or every month," "Opinion Pol" should be read "opinion on student politics in campus" and "Mat/HighSchool" indicates "parents who have attained Matriculation or High school." The following are the student organizations mentioned. DSU:

Democratic Students' Union, supporter of the Communist Party of India Maoist CPI(Maoist). It usually does not contest JNU student elections. DSF: Democratic Students' Federation, splinter group of SFI, associated to Left Collective and Young Bengal in West Bengal. AISA: All India Students Association, student wing of Communist Party of India Marxist-Leninist CPI(ML). SFI: Students' Federation of India, student wing of Communist Party of India Marxist CPI(M). NSUI: National Students' Union of India, student wing of the Indian National Congress. AISF: All India Students Federation, student wing of Communist Party of India CPI. UDSF: United Dalit Students' Forum, sympathizer of the Bahujan Samaj Party (Majority People's Party) BSP. It does not contest JNU student elections. ABVP: Akhil Bharatiya Vidyarthi Parishad (All Indian Student Council), student wing of Rashtriya Swayamsevak Sangh (National Volunteer Corps) RSS. Strongly supports the current Hindu nationalist party in power, the Bharatiya Janata Party (Indian People's Party) BJP.

Source: Martelli's Attitude Survey on Politics in JNU (2014-15), Multiple Factorial Analysis map by author. The full forms of student organizations can be found in Martelli (2020: Figure1).

The increasing size of student cohorts as well as the fast-growing privatization of higher education since the 1990s is having long-lasting effects on the conduct of student politics. Contributing to the portrayal of student participation in public affairs as unruly obstacles to both employment and access to educational goods, these two factors are fostering what Chatterjee (2012) describes as antipolitical politics. Within this framework, student politics is made responsible for "holding the education and campus experience hostage" (Snellinger 2018). Lukose (2006) for instance considers educated youth as a "gendered category of consumption." She describes how in various South Asian spaces such as Kerala (India), students assert the ban of general strikes in the name of respect for public property and a well-mannered use of the public space (Lukose 2009). Rejecting the morally "dirty" participation in organized politics, the majority of youth in Nepal are considered by Liechty (2003) as a vanguard of middle- 
class consumerism. Within such a template, antipolitical politics can take the form of youth-led protests against corrupt politicians, as was the case of the Anna Hazare movement in India (Tawa Lama-Rewal 2018). Fetishizing notions such as merit, this strand of politics negates the existence of social divisions, often contributing to their reproduction. For instance, the caste-neutral narrative of academic achievement at work in the reputed Indian Institutes of Technology (IITs) often benefits upper caste students. Indeed, as they inherit higher abilities to valorize their soft skills (Fernandez 2018) and their insider's knowledge of most profitable admission and placement strategies (Henry and Ferry 2017), they are able to transform their privileges into narratives of merit. However, while IITs' administration and upper caste students advocate castelessness to curb positive discrimination programs in India (Deshpande 2013), social divisions based on caste are reinforced on campus through sartorial and language differentiation (Subramanian 2019) as well as endogamous participation in clubs and societies. Overall, such practices contribute to the labeling of organized politics strictly in terms of corruption, immorality, unruliness and timewaste (Osella 1998; Sitapati 2011; Chatterjee 2016; Jeffrey and Dyson 2014), thus comforting a disciplining public discourse on political activities in educational institutions (Lyngdoh 2006; Teltumbde 2019).

13 Away from centers of excellence often located in state capitals and major urban centers, student politics in provincial towns are often seen as a way for young individuals to secure material benefits through brokerage and networking for political mileage, even if these activities sit uneasily with ascriptions to notions of public service, social devotion, honesty, largesse, moral purity and principled honesty that emanates from the field of student activism (Ruud 2001; Banerjee 2008; Nielsen 2012). In place of selfless "social workers" (Alm 2010), political youth are often moved by aspirations to social success grounded in economic benefits. In Bangladesh, Ruud (2010) and Andersen (2014) find that students looking for political careers and relations (Andersen 2016) are central in allocating hostel seats in exchange for student participation in protests (also Price and Ruud 2012). Jeffrey (2010), whose respondents display a resolute anti-political tone-like those of Lukose (2009)-shows how student leaders from the Jat caste in western Uttar Pradesh (India) become intermediaries between local state officials and private educational entrepreneurs. Thus, brokerage by student leaders in Northern India often appears to operationalize caste-based aspirations to control campus spaces, pushing student activists to compete for the leadership of their caste community (Kumar 2012). In several studies set both in Pakistan and India, urban youth do not seem to be moved by grand narratives, but rather by appeals to masculinity, fun and individualization. This is often manifested through acts of violence, whether in the name of a party (Verkaiik 2004) or Hindu supremacism (Hansen 1999), both offline and online (Sharma 2019a).

However, occurrences of self-gain do not preclude students' ideological commitments. The ideological premises associated with armed insurgency are often weaved around youthful desires to escape the control of elders, both in India (Shah 2006; 2018) and Nepal (Zharkevich 2009). When compared to non-political youth, the moral standing of heroic and "utopic" commitments to change society becomes the main drive for the activism of Nepali youth (Hirslund 2012; 2018). In contemporary Bangladesh (Suykens 2018), and in the post-civil war context in Nepal (1996-2006), such endeavors are substantiated by a Brahminic war culture of sacrifice (Lecomte-Tilouine 2006), 
martyrdom (Ramirez 2002; Zharkevich 2009) and struggle (Snellinger 2006), constantly renegotiated in the light of the unsavory compromises of electoral politics (Snellinger 2018). Student politics therefore exemplifies the tension between "politics as usual" and political idealism; the latter having further potential currency when the campus is separated from the "vicissitudes of the real world" (Bourdieu 2007:8). Ahmad (2009) for instance indicates that the campus-based radical student organization Students' Islamic Movement of India (SIMI) emerged in India's Aligarh Muslim University because it did not have to abide by the democratic beliefs of Muslim constituencies outside campus. Contrary to that, its rival, the Students Islamic Organisation of India (SIO), aligned with the democratization trajectory of its parental organization (the Jamaat-e-Islami), which prevented it from radicalizing in the wake of the increasingly assertive anti-Muslim agenda of Hindu nationalists at the turn of the 1990s. Campuses also emerge as important incubators of feminist and queer groups (Martelli 2020) as well as spaces of contestation of dominant nationalist narratives (Singh and Dasgupta 2019). In the light of such evidence, it is necessary to revise the reach of the many studies portraying students as inevitably de-politicized after the colonial period (Altbach 1969, 1970a, 1970b, Mehta 1971; Vidyarthi 1976a, Chopra 1978).

It is tempting to "stick" homogenizing and straightjacketing ideological tags to specific universities, which end up flattering out in-campus rivalries. Here are some of them: Marxism in Tribhuvan University (Kathmandu, Nepal), Jawaharlal Nehru University (Delhi, India), Jadavpur University, Presidency University (West Bengal, India) and colleges in Kannur (Kerala, India); ethno-nationalism in Punjab University (Punjab, Pakistan), Jaffna University (Tamil Sri Lanka), Banaras Hindu University (Uttar Pradesh, India) and Guwahati University (Assam, India); minority and Dalit politics in Baluchistan University (Baluchistan, Pakistan), Hyderabad Central University (Telangana, India) and Aligarh Muslim University (Uttar Pradesh, India); reproduction of caste dominance in Allahabad University, Chaudhary Charan Singh University Meerut and Patna University (Uttar Pradesh and Bihar, India); muscle politics in Rajshahi University and Dhaka University (central Bangladesh). Two overarching elements bind the politics of these various sites of student contention together and link them to the broader South Asia scenario. First, they are always male dominated, making university politics a playground for the political forging of assertive middleclass masculinities in South Asia (Lukose 2009). Second, student protests are often characterized by their ability to present grievances to a "disembodied" state (Kaviraj 2005). Such unfaltering enchantment of educated youth with an elusive institution makes the state the "central repository of people's moral aspirations" (Kaviraj 2005:295) despite the shortcomings of its main components (government, administration, police, army). The public-funded character of politicized universities complicates the relationship of student politics with the administration and the ruling dispensation. In those, students are supposed to embody simultaneously the aspirations of the state and of wider society: this tension is important to make sense of the regional and national political significance of student politics. From a functional point of view, public universities favor social mobility of incipient elite (Altbach 1969) and contribute to the selection of state manpower (Mayer and Rubinson 1972). From a symbolic point of view, they "signify the status of nationhood" (Burawoy 1976:82). Through institutional arrangements on campus (such as positive discrimination for deprived students), such educational spaces mediate between the elite and subaltern, contributing both to the formulation of a national identity and to the reformist agenda 
of the state (Deshpande 2016). Because public universities are embodiments of the South Asian public sphere, institutional attacks on them-notably through the privatization of higher education and the vilification of student activism as antinational (Singh and Dasgupta 2018)-are indubitable markers of illiberalism.

Student politics in South Asia entertains a desire to access the state, notably through their links with political parties. This is the case because student activism constitutes a springboard for future leadership (Hazary 1987; Snellinger 2019), in particular when harnessed to regional (e.g. the Bodoland movement in India's Assam), and national movements (e.g. Maoist youth in Nepal or the Telangana movement in India). In the absence of such movements, aspirational politicians tend to invest in select students' union elections-in Dhaka University in Bangladesh, or in Kumaun University and Delhi University in India to cite a few-through self-funding in the hope of securing networks and visibility to get a ticket from a national political party (Oommen 1974; Leah 2019). As many universities do not conduct (or have banned) elections of student representatives, agitation and patronage become the only alleys to win favors of political parties.

17 Albeit ethnographically rich, regional approaches to student politics tend to reduce university sites to one overarching ideology and social practice, while overlooking how such construct emerges out of value-based forms of political competition among agonistic student groups (Ahmad 2009; Nelson 2011; Martelli 2020). For instance, during the sixties, Christiansen (2020) indicates that the Leftist party of the National Awami League (NAP) dominating student politics in Dhaka University was ideologically structured around the conflict between a pro-Soviet and a pro-Maoist faction. Adopting a more diachronic fashion, Martelli (2018) suggests that the Left in JNU is not a homogenous bloc, but a set of rival groups that produced three distinguishable ideological narratives. ${ }^{4}$ Consequently, ideology in campus can be understood as a result of shifting identity markers, indexing personal political ambition and factional positioning (Garalytė 2020; Schulz 2020).

18 The regional context is a crucial (if not the main) parameter accounting for the variability of student politics in South Asia. While many of them invoke the legacies of various nationalist movements for independence (Reddy 1947; Rajimwale 2001; Wilkinson 2019; Christiansen 2019), student mobilizations are shaped by the sociocultural dynamics in which they emerge. For instance, the aforementioned $1974 \mathrm{JP}$ movement in India combined invocations to the glorious Indian freedom struggle for independence, while reacting to local distress, such as the doubling price of food grain in the state of Bihar. Particularly active in peripheral and borderland spaces, students appear to have a crucial role in regional movements for linguistic recognition and state autonomy, whether in Sindh, Baluchistan, Telangana, Tamil Nadu, Kashmir, Assam, Mizoram or Nagaland (Forrester 1966; Baruah 2014; Deka 2015; Levesque 2019; Pathania 2018; Paracha 2019; Sharma 2019b). They take the form of anti-Hindi or anti-Urdu protests, ethnic and tribal rebellions and claims for substantial self-rule.

19 Despite the importance of these mobilizations, an overemphasis on "movements of identification" might overshadow another emerging type of student mobilization based on what Rosanvallon (1998) calls "movements of expression," that is those movements of young collectives forged by generational experiences and situations rather than fixed identities (see also McDonald 2004). Structured by online communities which connect atomized experiments of overwhelming historical events 
(Percheron 1991, 1993), such as the triumph of Hindu nationalism in India or the unfaltering moral policing of women in South Asia, educated youth can turn passive networks into organized resistance (Bayat 2010). The formalization of such student mobilization, in which self-expression and concerns over quality of life gain gradually more prominence among educated youth globally (Inglehart 2008), does fuel students' initiative to reclaim individual autonomy for women, including the 2014 Kiss of Love protest in Kerala, the Pinjra Tod movement in India's capital as well as numerous attempts to reclaim patriarchal public spaces through social media campaigns-with names such as Why Loiter, Meet to Sleep or Happy to Bleed (Martelli 2017; Savory Fuller 2018)..$^{5}$ This complicates our representations of educated youth politics, which tend to provide stylized depictions of student years as inherently agitational, undisciplined or revolutionary, thus blanketly imposing ahistorical psychological generalizations on the multifaceted socio-political experience of students. In order to accurately represent the political significance of students in South Asia, we go on to unpack four common clichés structuring the study of educated youth and politics in South Asia.

\section{Challenging Student Leadership's Essentializations: Heroes, Entrepreneurs, Villains and Inheritors}

While the historical importance of students in reformist and revolutionary politics in the Global South is indisputable (Gill and De Fronzo 2009), a series of decontextualized normative assumptions about the political potential of educated youth obliterate generational effects and straitjacket them into sets of psychologizing postures: the revolutionary lion heart, the innovative entrepreneur, the dangerous deviant and the dynastic heir (Schwarz and Oettler 2017). As we deconstruct these four canvasses of educated youth, we stress the political consequences of the formation of students' social capital and its importance in establishing attributes of leadership. It is of prime importance to identify both scholarly and developmentalist essentializations of youth as they obfuscate the understanding of the political significance of educated youth in contemporary South Asia, notably when they assign deterministic rationales to youthbased mobilizations. By shifting the focus from what the educated youth inherently "is," to the empirical mechanisms of production of their subjectivities in the region, we not only deconstruct limiting analytical frames, but also pave the way for the introduction of the notion of generational communities, which precisely emphasize collective meaning production.

\section{The Heroes}

21 Let us start with the first of such approaches. Marxist understandings of youth as subculture, epitomized by the 'Birmingham School' in the early 1980s (Jenkins 1983; Lave et al.1992), gave specific emphasis to the youth as a form of opposition against class oppression. The idiosyncratic approach to the politics of youth is often associated with the idiom popularized by Marx and Engels (Tucker 1978) labelling the youth as the "alchemists of the revolution" (see also Jeffrey 2013). Most accounts of the youth by communist organizations in South Asia adhere to this approach and depict the Indian youth as a potential force of agitation against the establishment (Rudolph and 
Rudolph 1987; Paracha 2019). Various manifestos and press releases of South Asian Communist and Maoist parties emphasize the rebellious nature of students. ${ }^{6}$ According to these views, student political activists carry an inherent but mostly latent ability to reject mainstream careerist party politics. They can "acquire a heightened or radical consciousness through ideological engagement and praxis in order to transform aspects of society through the political process" (De Souza 2004). Portrayed as a courageous vanguard challenging gerontocratic regimes, students become the symbol of resistance to oppression rather than a historically embedded category. However, even if generations as age cohorts experience value change in rapidly changing economies (Inglehart 2006), evidence shows that such age groups in South Asia are not always politically distinguishable from older cohorts (Kumar 2019). It is only when we comprehend generations as communities of experience (Percheron 1993) engaged in self-making that student politics becomes a relevant axiom to understand engagements with "high-risk activism" (McAdam 1988).

\section{The Entrepreneurs}

This type of othering, emerging out of the perception of students as necessarily utopian and revolutionary is diametrically opposed to developmentalist approaches in vogue in Pakistan, India, Nepal, Bangladesh and Sri Lanka. Equally diligent in othering, they have promoted the image of educated youth as a source of non-political entrepreneurial potential (Robehmed 2015). International agencies conceive the demographic surge of educated youth as an innovative potential waiting to be unleashed, individualizing and depoliticizing their difficulties in pursuing their business projects (Siroux 2008). For instance, the South Asia program of the World Bank "Youth Solutions!" (2013) promises to empower youth through funding NGOs promoting Information Technology (IT) skills. Similarly, transnational organizations, such as the Education Commission, aim to challenge "regression to group allegiance" through fostering education in the Global South (2016). While agreeing on the fact that the overall rise in educational level has enabled youth to emerge as entrepreneurial leaders, Krishna $(2002,2007)$ demonstrates that in western India, such silent revolutions have not depoliticized educated youth but given them political roles instead. The crumbling of birth communities as building blocks for votes, increased state expenditure on development in rural areas, and the structural weakness of political parties has had tremendous impact on local political intermediation. These have turned educated youth carrying out vigorous and ingenious legwork on the ground into intermediaries between the state, university administration, admission seekers and households (Jeffrey and Young 2012; Young, Kumar and Jeffrey 2016). This has established them as for-profit brokers, community benefactors and vote aggregators for political parties-in place of village headmen, older community leaders and big landowners (Krishna 2011; Poonam 2018).

\section{The Villains}

Contrary to approaches depicting the youth as dormant entrepreneurial capital or as the spearhead of revolutionary resistance, other accounts portray the youth as a category of social deviance, and a potential source of delinquency and conflict with older generations (Cohen and Young 1981). Deviance in South Asia and elsewhere is 
often associated with the psychologically destabilizing (Morch 1994; Hudon and Fournier 2012) status of youth as unfinished adults and "emerging adulthood" (Arnett 1994, 1998, 2001; Arnett and Taber 1994; Aronson 2008), thus establishing the precariousness and instability of the pre-adult phase (Hall [1904]1972; Steinberg 2010; Crone et al. 2016). Because "youth" here means the transition from more established social categories of childhood to the independent unknown of adulthood, it embodies developmental "instability" and potential "anti-social" commitments.

In the deviant approach, pioneered by American sociology in the interwar period-and championed by the sociology department of the University of Chicago (Bulmer 1986) the youth tend to constitute alternative systems of symbolic meaning for individuals sharing a similar subculture (Cohen 1955) and labelled "deviant" by members of the dominant culture (Becker 1963). Explanations of student protests in the postindependence South Asian context, in particular in the 1970s and 1980s, focus mainly on deviance and inter-generational conflicts. Adulthood in the making is seen as turbulent in terms of changes in status (Fusselland and Furstenbenrg 2005), such that potentially radical political commitments often happen at that fateful critical moment inherently related to the development of the individual's personal identity (Erikson 1980).

Fictional accounts of youth protesters as troublemakers are not rare in South Asia, as best exemplified by the case of Raju in the novel of S. Weeraperuma, Sunil: The Struggling Student (2009), in which a Sri Lankan up-and-coming young student leader, Raju, galvanizes protesters towards murder and loot. Salient in the scholarship on Indian youth, authors have focused on conflicts in values between parents and dependents (Rege 1971; Singhvi 1972) while others emphasize the weakening of traditional authority structures (Sinha and Gangrade 1971; Malik and Marquette 1974) in the family and at school (Shils 1968), and the alienation of youth from the decisionmaking processes of political institutions (Singh 1968b, Di Bona 1966; Ahluwalia 1972). As Shah (2004) summarizes, the prevalent theory adopted by Indian sociologists and social psychologists in the 1960s and 1970s crystallized the notion of the "generation gap," marked by youth impatience to acquire autonomy, urging them to get rid of their tutelage and enter conflicts with adults (Kakar and Chowdhary 1970; S. L. Sharma 1971). Additionally, through focusing on the conflict between generations, this literature relied heavily on the idea of "student indiscipline," stressing the inarticulate feelings of educated youth. Altbach (1970) reports that 5 percent of student agitations were due to non-academic issues in 1964; 5 percent in 1965; and 17.4 in 1966. Such indiscipline is often used as a synonym for goondaism (criminal behavior) (Oommen 1974; Sinha 1975), violent disturbances (Cormack 1961; Gusfield 1970; Di Bona 1966; Singh 1968, Ross 1969; Vidyarthi 1976) and a recurrent effort to bribe voters in order to win student elections and negotiate elective posts and further political careers.

\section{The Inheritors}

Through renegotiating these representations in light of the ability of politicized students to fashion youthfulness locally, we examine educated youth as both makers and receivers of political narratives. We conceive them as not only an important section of brokers, voters and kingmakers; we also point at their functional share in the elected body. Following Chandra (2016), it appears that young politicians-graduates or 
dropouts-backed by influential families are able to represent the "youngest ever electorate" (Rukmini 2014) and because of their presence, old patriarchs are more likely to step down in order to transfer power to them. Among the members of the Indian parliament elected in 2014; more than 20 percent are from political families (Chandra 2016), and the ruling party renominated seventy percent of its dynastic parliamentarians in the 2019 national elections. French (2011) has counted that among elected members of the then Indian parliament aged 40 or below, two-thirds had a political family background. Thus, in a democratic context, young heirs are seen as capable of compensating for the organizational weakness of their party (Chandra and Umaira 2011; Amundsen 2013; Carlevan 2018).

If it is true that older generations, parents, the state, faculty, politicians and figures of authority do intervene to construct stereotypical and irreconcilable portraits of students and their politics, then what is the possible framework under which we can assess their relevance in South Asia? As the four topoi we have outlined tend to depict youth as actualization processes (fulfilled or not) of set postures, they tend to trivialize the heuristic mechanisms by which youth iteratively engage and interpret collectively their everyday experiences politically. Free from these four characterization "shortcuts," we are now better equipped to understand the way by which collective political sensemaking by educated youth is produced. To that end, we analyze in the next section why students act as generational communities, standing either as localized enforcers or negotiators of South Asian political modernity.

\section{Generational Communities in South Asia: Navigating Ideal Types}

Emerging from this account, the two main difficulties of recovering the worldview patterns of campus-based politics are, on the one hand, their strong socio-economic and territorial variability, and on the other, the prevalence of competing fixed representations of what "studenthood" does to political engagements. In order to account for the changeability of student politics, we suggest that they could be better understood as generational communities. We understand them as cohorts of students shaping collectively the meaning they attach to their youthfulness through embedding socially located-i.e. cohort-based-interpretations of diffuse and marking sociopolitical turns (Mannheim [1928]1952; Percheron 1991; Jennings 2002). Moving from there, we argue that generational communities depend on the selective activation of the political potentialities of community life. We further suggest that student politics is pursued differently according to the everyday functioning of such communities, which are located somewhere in between two functional poles we identify in this section: natural communities on the one hand, and political communities on the other. In "real world" situations however, generational communities are to be found somewhere in between its natural and political avatars, as in concrete empirical terms, no pure type exists.

While keeping as reference point long existing and historically constituted communities, our specific understanding of the political potential of student collectives is temporal, spatial, social, aspirational and symbolic. The student years can be characterized by what Bayat (2017) calls "structural irresponsibility," that is the relative tendency of youth to experience forms of autonomy away from familial and 
professional duties. This indicates lower time and material constraints to political participation, which is referred to as high biographical availability (McAdam 1986:70; Beyerlein and Hipp 2006). We understand the cost of student activism as the risk, money, time, and energy attached to political participation. On average, what makes this cost high-such as preparing for exams-is usually still lower than, let us say, breadwinning among the working class (Beyerlein and Bergstrand 2013). The relative spatial (and virtual) separateness of student collectives from the parental environment makes the campus a potential staging ground for consciousness raising, as developed in the literature on "free spaces" (Polletta 1999) and related ecologies (for a list, see Martelli 2020:7). ${ }^{7}$ An examination of the latent political conduciveness of dense networks of co-presence in small-scale settings such as student dorms (hostels), campus lounges and public meeting hangouts, is a prerequisite to the understanding of the way mutual influence is produced before, during and after student-led social movements (Zhao 1998). Characterized by sustained social intercourse, student communities are also bound by common future-oriented aspirations for upward social mobility. Strong capacities to aspire are grounded in rich social experiences (Appadurai 2004; Bok 2010), strengthening the confidence that participation in collective action can make a difference and bring about desired changes, hence bolstering the sense of efficacy (Klandermans 1984; Klandermans et al. 2008) of aggrieved students. The political potential of students is also symbolic. They are, in a metonymic fashion, representing for the public opinion two broader feel-good categories (the youth and the nation) and one auspicious promise (the future) (Pandey 2006). Partly because of the gender and class-cum-caste diversity of the student population in a handful of public universities (Deshpande 2016), student politics and its representatives can claim to personify a popular modality (Pandey 2016), ultimately legitimizing themselves as a national (or regional), nonelected, counter-public (Fraser 1990).

The structure of this section is fourfold. First, it briefly presents the empirical advantages of using communities of educated youth as our operational unit of analysis (1). This leads us to introduce the concept of generational communities; we explain how it can facilitate understandings of the way political subjectivities are collectively formed and structured within coherent spaces of sensemaking. We then move to differentiate between two ideal types of generational communities, namely natural and political ones (2). We also map out the processes of transition between natural and political generational communities and introduce a cautionary notice regarding mixed cases and the limitations inherent in classificatory endeavors (3). Lastly, the discussion expands the potential use of generational communities to explore the interface between student activism and other forms of political participation away from educational arenas. We conclude by evoking the possibility of scrutinizing generational communities to research phases of political abeyance among educated youth. We also outline some of the long-term biographical consequences of active and passive participation in such collectives (4).

\section{Communities as Units of Sensemaking}

31 Before inquiring about the way students' political potential is actualized in practice, let us reassert why student groups can be labelled as communities, and why these are concretely generational. We consider student collectives as communities when they 
enact a physical or virtual space between members (Wellman and Leighton 1979), when they favor the development of social ties and networks connecting members (Schafer 2019), and when they permit the emergence of meaningful interactions binding members together (Kusenbach 2006). In turn, communities of educated youth display the following features. First, they make possible fresh encounters and a new flow of habits distinguishable from primary socializations and kinship ties such as family and neighborhood circles (Schutz 1976; Etzioni 2014). This is particularly true of "legitimate peripheral participants," that is freshmen and sophomores (Lave and Wenger 1991). Student communities are therefore third spaces that are, distinguishable from both home and work (Oldenburg 1999). While several studies discuss the adjustments made by students to reduce the tension between their original social milieu and the university experience, few examine the political consequences of such self-work (Granfield 1991; Aries and Seider 2005; Reay, Crozier, and Clayton 2009; Lehmann 2009; Pasquali 2010; Naudet 2018). ${ }^{8}$

The insistence of particularistic features emerging out of student collectives is important as it signals a possibility of differential politics based on a distinguishable social capital (Coleman 1988) that displays at least incipient levels of the followings: social connectedness (Putnam 1995), shared beliefs and subjectivities (McAdam 1982, 2000), bonds and harmonious interests (Allen 1993), repositories of values (Townsend and Hansen 2001), common concerns (Kemmis 1992) and shared experiences (Barber 1998). In the context of higher education, that means a certain collective experience of academic and non-academic life. In theory, student communities are also what the Turners (V.Turner 1969, 1974; E. Turner 2012) have called "communitas," that lack social structures and hierarchies specific of interstitial life moments, that is those separating from a previous social role, and preceding aggregation to a new one. Among student groups, transient state can be prolonged and in practice is not as egalitarian as assumed; yet these communities tend to be characterized by a veil of equality that level status distinctions (Oldenburg 1999).

Therefore, since student collectives act as communities that encroach to an extent on traditional social divides, what binds them together? This introduction suggests that they have in common attempts to self-fashion in relation to the pervasive or traumatic events that structure South Asian modernity, whether it is liberalization or ethnonationalism. The act of biographical configuration, acute during student years is therefore inherently generational. Building on notions of generational unit (Mannheim [1928]1952) and social generation (Pilcher 1994) we understand student generations as social locations, that are an aggregation of those individuals engaged in higher education, sharing in common a socially located experience and a common exposure to formative events (Fendrich 1974; Dalton 1977; Fillieule 2013; Della Porta 2019). Thus, we indicate that the actualization of the political potential of educated youth boils down to a differential acquisition of cohort-based subjectivities and a differential forfeit of tenets of previous generations (Guha 1997). Hence, for us student generations are less age-based biological constructs than historicized cohorts (Pilcher 1994).

34 The choice of the notion of generational community contributes to solving a series of impasses in the field of youth politics involved in higher education. First, because communities structure engagements with formal electoral politics (mainly as votebanks) while simultaneously routinizing a range of attitudes and worldviews, they help 
us operationalize the interplay between "big P" and "small p" strands of politics, at the crossroads of historical turns, party politics, students' biographical experiences and collective exposures to historical developments. Conversely, the unpacking of generational communities enriches our understanding of how student politics mediates between the state and individual students. Second, the 'community approach' facilitates the understanding of geographical variation in student politics. Since communities are defined by physical or virtual boundaries, they are inherently territorial, grounding macro dynamics within the idiosyncratic realm of campus cohorts, academic circles, age-based loitering and online constituencies. The fact that communities socialize meaning-making practices helps us contextualize some of the homogenizing features of youthful modernity in South Asia-in particular conservative family upbringings, post-liberalization consumerism and mass unemployment-in light of the cultural dynamics of generational associational ties. To sum up, scrutinizing student communities tells us how, on an everyday basis, the constitutive features of South Asian politics are either reinforced or challenged locally. Generational communities, as the arenas in which one's youth is performed, act as compasses: they prefigure change or consolidate political realities.

While community-based subjectivities of students are shaped by common anguishes and shared gendered aspirations for social recognition-through job-finding, marriage and motherhood-they are fashioned differently depending on a range of factors at work within such collectives. One example is the circulation of political idioms from one micro-cohort (Whittier 1997) to the other through the authoritative intervention of senior student activists who transmit their political capital to new batches of freshers (Martelli and Ari 2018). Another mechanism involves the spilling over of value-based political idioms from one group to the other under the effect of competing student organizations fighting for representation (Martelli 2020).

By looking at educated youth as generational communities, it becomes easier to understand how substantive political transfigurations of student attitudes tend to be irrigated by politically informed friendships, romances, peer-to-peer argumentation, student-professor exchanges and learning from charismatic youth (Koskimaki 2020). When such politics is grounded in (at least partly) insulated educational spaces, it tends to develop a character of its own. This explains why certain institutional higher education sites come to acquire the "flavor," that is the public image and reputation of the student-run civil society they host. For instance, in Pakistan, Punjab University has historically garnered religious-based student activism (Nasr 1992; Javid 2020) while the University of Sindh hosts the ethno-nationalist aspirations of Sindhis (Levesque 2020). Because generational communities enact forms of collective belonging based on shared characteristics that are either ascriptive or voluntary (Shachar 2003; Staheli 2008), they can accommodate the various streams of student politics in South Asia, whether ethic-, grievance- or value-based (Altbach 2006; Martelli 2018a). The focus on the community enables a departure from the academic scholarship in the 1970s-1980s, which approached student politics only vis-à-vis adulthood (Durham 2004; Nisbett 2007; Jeffrey 2009), mainly as acts of indiscipline emerging from age-related psychological disturbances and angst towards parents (c.f. previous section). Neither strictly biological nor psychological, the politics among educated youth cannot be solely defined stylistically and teleologically as rebellious, revolutionary, socially deviant, entrepreneurial or dynastic. 


\section{Natural vs Political Generational Communities}

The accounting for the various avatars of political participation among student collectives leads us to distinguish between two types of generational communities; natural on the one hand and political on the other hand. We propose to understand natural communities as collectives in which student politics' main outcome is to reproduce hierarchies and practices existing outside campus spaces. Student groups are, in this perspective, cohorts to be captured by representatives of political organizations and other non-student communities. Acting as captive public, university groups are then mobilized predominantly for political mileage, receiving individual (and often material) benefits in exchange for support. The broad political contour of the natural community is the limited scope of student participation, which is "mainly oriented around university issues, especially the welfare of students, administration of higher education, and distribution of patronage associated with the privatization of education" (Jeffrey 2010:131). In this context, ideologies play a secondary role in the conduct of student politics, which is determined instead by male-dominated entrepreneurs in the pursuit of status and aspirational upliftment. Advantages derived are mostly material-through various forms of brokerage-and political-through securing tickets and advancement within political parties. While brokerage fosters logics of differentiation between brokers and recipients, it also fosters cohesiveness among students through enabling access to educational resources while forging economic and social interdependencies. In natural communities, student activists often seek ways for their community to extend its social domination onto economically profitable markets such as private education. As a result, natural communities are weaved around structures such as coaching centers and corrupt administrations, prospering along profit-heavy recruitment procedures and low-value diplomas, ultimately making patronage and collusion with officials a key to social advancement. In this context, student politics appears as an instrument to invest in the public space in the hope of asserting a set of dominant identities: the man, the leader, the fixer, the caste or religious head. In natural communities permeated by economic liberalization, political self-fashioning is articulated around notions of consumption, virility and at times "muscle" power (Ruud 2010). Assertions of moral righteousness by students in these spaces are practically contradicted by their art to constantly transgress them according to the need of the hour. The study of self-presentations in natural communities is important in order to understand broader political trends at national and regional levels: the contribution of leisure, consumption and moral aspirations to communal politics in India and Pakistan, the desire of modernity in the Maoist movement in Nepal or the majoritarian impulses in the Singhalese ethnic nationalism in Sri Lanka. All-in-all, natural communities tend to enable the generational re-rooting of forms of hegemony, sometimes through the elaboration of a politically neutral vocabulary (i.e. the notion of merit in prestigious Indian Institutes of Technologies) that masks politically constituted inequalities on the lines of caste, gender, class, religion or ethnic identities. We primarily view consumerism as a facilitator of natural communities as we acknowledge demand-based economic liberalization as one of the main instruments of social reproduction in contemporary South Asia. However, we accept the idea that consumption is occasionally tied to broader transformative agendas, in particular when such consumption is subsumed within lower caste 
emancipatory politics or some streams of feminist activism. While idioms such as "ritual pollution" or "patriarchy" can be mitigated through the active display of sartorial assertiveness and goods-flaunting in the public space, such consumerist practices remain widely associated to the dominant narratives of wealth accumulation and materialist modernity at work outside campus spaces.

In both natural communities and what we now go on calling political communities, students are industriously claiming representations of their generation through fashioning their youthfulness-thus activating in their own way the political potential of educational arenas. That having been said, we argue that political communities are distinguishable from natural communities in their aspiration to politicize students differently. Contrary to their counterparts, political communities are characterized by their ambition to engage with-and at times generate-explicit ideational values, hence moving beyond campus-specific material demands. So even when the daily routine of student politics is articulated around access to welfare, such welfarism is tied by their proponents to a larger transformative agenda: this broader goal could be the formation of a Hindu kingdom according to ideological activists of the Akhil Bharatiya Vidyarthi Parishad (All Indian Student Council, ABVP), or the abolition of class divides across South Asia for the ideological lots among student-wings of communist organizations. On a routine basis, political communities distinguish themselves by their ability to instill prefigurative debates within campus spaces, thus displaying degrees of autonomy from the larger polity. The ideational debates fueled by political competition turn select educational spaces into semi-independent public spheres, carrying the potential of acting as counter public. Because the crafting of political selves within political communities is enabled through value-based agonism, it leaves space for the participation of new voices and gives them a chance to contest established discourses. Emerging worldviews such as feminism, Dalit activism and political ecology find better potential alleys to flourish in political communities than in natural communities. Because of their integrative effects, political communities favor proximity between ideas, engendering cross-fertilization and the reformation of dominant frames in society. Contrary to natural communities which implement and reproduce dominant socio-political modalities, political communities attempt to negotiate them, influencing back regional and national collectives with the output of their political churning. To further explicate the distinction between the two student communities, we categorize below a series of student-led movements in South Asia according to the ideal types they lean towards.

Figure 2: Examples of student-led movements enacted by predominantly political or natural generational communities

\begin{tabular}{|c|c|c|c|c|c|c|}
\hline Case study & Community & Type of student politics & Educational setting & Dominant social profiles & Region & Time frame \\
\hline $\begin{array}{l}\text { Lukose } 2009 \\
\text { Jeffrey } 2010 \\
\text { Ruud } 2010 \\
\text { Javid } 2020\end{array}$ & $\begin{array}{l}\text { Natural } \\
\text { Natural } \\
\text { Natural } \\
\text { Natural }\end{array}$ & $\begin{array}{l}\text { Anti-strike protests } \\
\text { University-issues protests } \\
\text { Crowd-making party politics } \\
\text { Patronage party politics }\end{array}$ & $\begin{array}{l}\text { Private nonmetropolitan college } \\
\text { Public state university } \\
\text { Capital-based public university } \\
\text { Mostly public university(ies) }\end{array}$ & $\begin{array}{l}\text { Classes } \\
\text { castes } \\
\text { ity }\end{array}$ & $\begin{array}{l}\text { Kerala, India } \\
\text { Uttar Pradesh, India } \\
\text { Dhaka, Bangladesh } \\
\text { Punjab, Pakistan }\end{array}$ & $\begin{array}{l}\text { Mid-1990s } \\
\text { Mid-2000s } \\
\text { End-2000s } \\
\text { Mid-2010s }\end{array}$ \\
\hline $\begin{array}{l}\text { Laurence } 2020 \\
\text { Hirslund } 2018 \\
\text { Gundimeda } 2009 \\
\text { Martelli } 2020\end{array}$ & $\begin{array}{l}\text { Political } \\
\text { Political } \\
\text { Political } \\
\text { Political }\end{array}$ & $\begin{array}{l}\text { Minority rights assertion } \\
\text { Utopian Maoist lobbyism } \\
\text { Cultural challenges to caste } \\
\text { Ideational cross-fertilization }\end{array}$ & $\begin{array}{l}\text { Regional central public university } \\
\text { Capital-based public university(ies) } \\
\text { Regional central public university } \\
\text { Capital-based central public university }\end{array}$ & $\begin{array}{l}\text { Ashraf-led Muslims } \\
\text { Urbann middle-classes } \\
\text { Dalit castes } \\
\text { North-Indian non-elites }\end{array}$ & $\begin{array}{l}\text { Uttar Pradesh, India } \\
\text { Kathmandu, Nepal } \\
\text { Telangana, India } \\
\text { Delhi, India }\end{array}$ & $\begin{array}{l}1965-1981 \\
2006-2017 \\
\text { Mid-2000s } \\
\text { Mid-2010s }\end{array}$ \\
\hline
\end{tabular}

The criterion of differentiation between natural and political communities is the degree to which public engagements of students are allocated to substantive valueoriented agendas for social transformations, both within and outside a given generational community. While the two community types host rivalries among student groups and individuals to secure political, economic or symbolic capital, commitments 
to social transformations in natural communities are strictly tied to material concerns and are aligned with dominant ideological frames and mainstream party structures infusing campus spaces. Let us take two examples of Figure 2. Jeffrey (2010), in his study of student politics in Western Uttar Pradesh notes that Jat political animators disregarded questions of national or international relevance, perpetuating nominally anti-corruption stands while encouraging it though siphoning off educational money for the construction of for-profit educational institutions. Here, commitment to social change is at best nominal, while actual politics is geared towards personal enrichment and the reproduction of Jat power in the region. In this case students tend to be reduced to a captive, natural community whose worldviews do not need to be altered to achieve political mileage. Contrary to this, Laurence (2020) shows how a campus such as Aligarh Muslim University (AMU) serves as a "laboratory for diverse forms of Muslim politics," enabling various ideological streams from campus diffuse nationally in order to question the then hegemonic discourse on secular nationalism of the Indian National Congress party. We can see that student politics, through demanding Muslim minority rights attempt to mobilize selectively values and positions within the broader polity to forge counter-narratives and pluralize political voices outside dominant party frameworks. Here the demand requires student activists to reshape the political understanding of campus cohorts, making the university the arena of a political community.

\section{From Natural to Political and Vice Versa}

A set of concordant factors enable generational communities to move from natural to political and vice versa. The collective engagements of generational communities with macro political events depend in part on the political socialization they shelter. Such socialization is fostered through the circulation of political ideas and frames between micro-cohorts of activists and younger micro-cohorts of individuals who have entered university more recently. The more active and organized the early adopters of valuebased political idioms, the faster it can circulate to other groups in campus and affect perceptions of the wider political scenario, hence nurturing the formation of political communities. The overall oppositional style of student politics does not only involve traditional repertoires of collective actions in South Asia (e.g. in North India, dharna or sit-ins, hartals/bandh or strike actions, juloos or marches, gherao or picketing), it also mobilizes a pamphleteer style of politics involving vituperative truth claiming. When

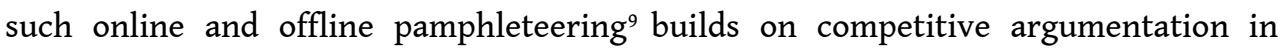
addition to "slanders" and other emotional tropes, it favors the transition from natural communities to political communities. The move from natural to political is further accelerated when the competition for student representation is articulated around ideational idioms, which favor the formation of political spillovers and the hybridization of ideologies. Both political communities and natural communities host political self-fashioning accounting for the way activists legitimize their public work. However, because in natural communities material demands are usually disconnected from any broader inclusive agenda, biographical reconfigurations of activists there tend not to aim at the symbolic representation of the weaker sections of the population; they instead perform responsiveness towards the students. Put otherwise, the singlehanded focus of student activists on "getting things done" drives political communities towards natural communities; such an agenda is not geared towards 
larger questions of wider social representation (Martin 2019). Natural and political communities are networked entities, showing affinities to similar types of generational communities. The interaction between these communities and the wider society are bolstered by students, but are also channeled by political parties and educational businesses, by state and international development agencies, and as part of interactions with neighboring spaces. They involve a wider set of actors, comprising community entrepreneurs, students' families and friendship, faculty, alumni, brokers, personnel of NGOs and members of caste associations. In that regard, what differentiates political communities from natural communities is their ability to act as nodal points for initiators and early political mobilizers who are able to organize student protesters, crystallize public grievances, act as a political symbol, coordinate actions and circulate repertoires of contention across university campuses. We elaborate this aspect further in the postscript of this issue, which engages with the student-triggered protests against the amendment to the access to the Indian citizenship which started in December 2019. Notwithstanding the academic limitations of commentaries on ongoing events, we outline the importance of students' political communities in converting grievances into collective action going beyond campus spaces.

The proposed dichotomy is not prescriptive nor essentialist but rather contextual, historical and processual in scope. This means that neither ideology nor any university space is fated to be bound to one type of student community. Hindu nationalist politics for instance could contribute to the making of both natural communities and political communities depending on the student context in which it unfolds. It qualifies as an expression of the political communities unfolding in and around Tribhuvan University (Nepal) and Jawaharlal Nehru University (India), where such activism intends to challenge leftist politics, thus contributing to an extent to the emergence of ideologically informed and argumentative cohorts. Contrary to that, Hindu nationalism provides the hegemonic tint to the natural community in and out Banaras Hindu University (India), where dissonant narratives apart from Hindu nationalism are difficult to foment (Dubey 2017; Pandey and Srinivasan 2019). Considering the richness and multiplicity of political experiences of educated youth, no student movement in South Asia does constitute a pure type. It results that political fashioning in educational institutions navigates somewhere in between the natural and political forms of generational communities identified here. As developed earlier, the particular determination of self-making patterns in natural and political communities depends both on structural and idiosyncratic factors. Students' exposure to social change and encompassing political events shape generational communities in common, yet the understandings and self-fashioning weaved around such impactful frames depend ultimately on the location of these student constituencies. In turn, such locations are imbued by the socio-cultural as well as educational contexts of the campus. Such contexts do not only vary according to the student composition, they are also affected by spatialized political competition, continuing cultural legacies, the strength of activists' networks and professorial as well as administrative support. These processes fundamentally depend on everyday intergenerational transmission between microcohorts of students (often from seniors to juniors), which results in the selective activation of the political potential of educated youth. 


\section{Researching Generational Communities: Internal Dynamics and External Interactions}

Due to the variability of student politics in the region, we do not venture into developing a comprehensive comparison between South Asian generational communities and its counterparts in the Global South and in the West. For instance, we do not at this stage address the question of whether natural communities are prevalent in South Asia as compared to other world regions. However, a few key variations can be kept in mind while attempting cross-regional assessments. Outstandingly, the " youthful modernity" of student politics in South Asia continues to be characterized by its quasi-exclusive masculine composition, the pervasiveness of post-colonial nationalist narratives and the frequent references to national independence struggles. The omnipresence of vertical conservative family upbringings means that for many South Asian youth, college years introduce a significant change. There, students often encounter a horizontal space where citizens carry the potential to discuss and learn as equals, at times implementing relative levels of inter-caste and gender-fluid intercourse. If we posit the existence of a scarcity of traditional public spheres in South Asia as compared to Western counterparts, this would mean that universities, as an archetype of such spaces have a comparatively higher role to play in hosting dissonant political discourses in the region. The more recent and selective experiments of generational communities with the consumerist practices of liberalization, as well as the entrenched unemployment and economic uncertainties of youth make them more responsive to materialistic aspirations and cultures when compared to European and North American counterparts. Youth in the latter countries give increasing emphasis on "postmaterialist" priorities such as quality of life, autonomy and self-expression (Abramson and Inglehart 1995; Inglehart 2007). Nevertheless, the increasing online penetration rate in South Asia might have equalizing political effects between the Global South and the West, notably through the introduction of more personalized strands of youth political participation and decreased needs of hierarchical political coordination, although the importance of organized political parties in the conduct of South Asian student politics remains significant. Last but not least, the more recent and rapid expansion of the private high education sector in South Asia seems to have longlasting detrimental consequences on the ability of universities in the region to host and act as political communities. Further studies could provide further insights on this hypothesized trend.

Three questions pertaining to the functioning of generational communities of students persist. First, in the wake of large-scale social movements involving students, how can we account for the large-scale coordination between the many generational communities and other social movement organizations and publics (Zald and Arsh 1966)? With the notable exception of Ray (1998), we do not know about the way interactions between activist collectives and their political field in South Asia affect the content and successes of their strand of politics. Generational communities need to be better located in their multi-organizational environment (Ray 1998:22), in which nonaffiliated groups and even individuals play an important role in the coordination of "passive networks"10 during long-lasting phases of political mobilization. The mechanisms by which non-unionized generational communities converge across social and regional landscapes deserve urgent inquiry. A second question pertains to the 
extent to which politicized student communities provide a ground for social movements in periods of abeyance (Taylor 1989; Taylor and Dahl Crossley 2013), mainly by providing dormant points of political socialization ahead of new cycles of contention. Lastly, generational communities could help us analyze the political, cultural and biographical consequences of student activism after university years (McAdam 1999; Fillieule 2005, 2009; Giugni 2007). What happens to the political selfmaking of students when it is extracted from the community in which it was cultivated? This question urges us to assess the durability, the life-long transformations as well as the durable sociological consequences of political engagements during student years.

\section{Overview of the Special Issue and Research Prospects}

This special issue consists of eight articles covering a range of student mobilizations in South Asia, grappling with concerns such as regional identity, gender, caste, religion and political ideology. It entails accounts combining macro, meso and micro perspectives, by locating student collectives within their larger political contexts, and gradually zooming in on personal accounts of particular individuals within their educational settings. The issue opens with the pan-Indian student mobilization during colonial times and ends with an intimate look at Dalit students' moralities. From a geographical standpoint, it explores political centers (i.e. Dhaka and New Delhi) and peripheries (i.e. Nainital and Sylhet) as well as processes that transgress national boundaries (i.e. anti-colonial struggles and global youth unrest in the 1960s).

The contributions of this special issue cannot be grouped into clear-cut thematic blocs. Rather we dichotomize them according to their methodological approach-either historical or ethnographic. Four articles(presented in a chronological order) are based on historical research on different time periods involving phases of intensification of student movements in South Asia. Though focusing on different contexts and time frames, these articles share a common thematic line-they are illustrative of how student activism relates to and depends on the broader political context. Particular attention is given to students' ability to influence mainstream political processes. This special issue also contains four ethnographic accounts focusing on recent developments in the field of student political activism in India (three case studies) and Bangladesh (one case study). They provide a perspective on everyday campus life and individual experiences amounting to expressions of "mundane political agency" (Häkli and Kallio 2018).

We start the historical journey into student political activism in South Asia by going back to late in the colonial period. The first account of the issue explores the consolidation and disintegration of the Indian student movement in the last decades of British Raj. Tom Wilkinson explores the rise and fall of the first pan-Indian student organization-the All India Student Federation (AISF). Created in 1936 as an organization that could serve as a platform for the all Indian student movement against British rule, AISF eventually became the locus where different political and religious identities and partisan interests crystallized, resulting ultimately in the organization's disintegration in 1950. One significant disagreement and split within the organization was along religious lines. With Hindu interests dominating AISF, Muslims felt alienated within the organization and finally revoked their support. The withdrawal of Muslim 
students from AISF was also influenced by the mobilization of Muslim students into All India Muslim Students Federation in Aligarh Muslim University, whose later developments are discussed by Gautier (2020). Another major split within the AISF emerged between Congress followers and Communists, who disagreed over India's support for British actions in World War II and the overall trajectory of the Indian independence movement. Wilkinson's analysis aptly shows how these rifts within the Indian student movement were influenced by the broader political processes at work at the national and international levels.

The second contribution takes us to Dhaka University campus in the 1960s, in the context of global youth unrest. Drawing on oral histories and written testimonies, Samantha Christiansen re-establishes the centrality and symbolic role of Dhaka University and the broader student movement in the history of Bangladesh. The account is not restricted to Dhaka University student activism and its national impact. Her central argument is that the student movement, structured around multidimensional identities manifested at different scales, local, regional and international. At the local level, students were concerned with economic stagnation in East Pakistan, and went on taking a central role in foregrounding Bangladesh's independence. Students actively challenged the provincial governor Abdul Monem Khan and fueled the government's efforts to suppress the movement. At the regional level, students took advantage of the Indo-Pakistani war to overthrow the regime of Ayoub Khan, thus achieving a landmark success in the history of student movements in South Asia. Meanwhile, on the international stage, students were motivated by the global student unrest against imperialism and the ideas of the New Left, which reflected in Bangladeshi newspapers. Christiansen's article provides insight into students' capacity to influence larger political processes. Students at Dhaka University were key players in Bangladesh's independence movement; they shaped major political debates and led a regime change, ultimately achieving, as Christiansen puts it, "what revolutionary young people across the world desired."

Focusing on a similar (though more extended) timeframe, Laurence Gautier examines Muslim politics in Aligarh Muslim University (AMU) in India's Uttar Pradesh. AMU has been a hotbed of Muslim culture and politics since its creation in 1875; taking an active role during India's Partition. Between 1965 and 1981 student activists and various other actors launched a campaign for AMU's minority status, attempting to increase the number of Muslims studying in the University in order to preserve its Muslim character. This initiative emerged as a broader political claim among Muslims. This was both due to the combined action of parties such as Jamiat Ulama and Jamaat-e-Islami and to the political neglect by the Congress government, which in turn strengthened feelings of marginalization among North Indian Muslims. Gautier argues that instead of reading the campaign for AMU's minority status as a sign of crisis of the then "Nehruvian consensus," we should instead interpret it as evidence of the emerging pluralization of Indian politics which subsequently led to the proliferation of interest and identity-based groups in the post-Emergency period. Gautier focuses on the ambivalent effects of AMU student politics on larger political processes. In a vein similar to that of Christiansen and Wilkinson, Gautier, speaks about students' capability to infuse national debates. AMU's campaign for minority rights, though emerging as a campus concern, transformed into a key Muslim issue, resonating among various social and interest groups far beyond the campus walls, giving an impetus to the formation of several Muslim political organizations. However, Gautier argues that the long-term 
effects of this mobilization were more ambivalent, as Muslim party politics emerging in the aftermath of the campaign was eventually fragmented by internal rivalries fanned by contentious emotional appeals. Nevertheless, the article concludes by insisting that "AMU remained a laboratory for diverse forms of Muslim politics." It is there that "alternative voices" among Muslims could emerge; they gradually deemphasized attention on minority identity issues, stressing instead on Muslims' socio-economic deprivations.

49 Hassan Javid's contribution explores the current state of affairs of student politics in Pakistani Punjab. He provides a detailed account of the development of student politics in the province from independence to present day, throwing light on ups and downs, successes and failures of student political mobilizations. Javid engages with the different ideological shades of these student movements, whether leftist, Islamist or ethnic. The trajectory of Pakistani student politics-from pluralization to decline and finally rebirth-appears to be largely dependent on the changing political regimes and their acrimonious interventions against student politics. The underlying question that guides Javid's paper is that of how student politics continue to survive under the state's repression and the continuing official ban of student unions. With this in mind, he examines the politics of three student organizations that are currently active in Punjab -PML-N Youth Wing (PYW), Insaf Student Federation (ISF) and Democratic Students Alliance (DSA). He identifies three distinguishable political strategies-PYW operates through patronage politics hand in hand with its parent party, ISF feeds on populist sentiments, while DSA retains a longstanding idealistic and progressive radical orientation, which limits the political success of the organization. Javid argues that current student activists cannot be compared to those previous student generations that grew to maturity in highly politicized and ideologically driven university campuses. DSA is the only student group resisting this change, while the other two organizations act as "non-ideological," "top-down creations" of the political parties, ultimately contributing to the ideological de-politization of Pakistani youth. Javid predicts that Pakistani student politics will likely develop along a similar trajectory, in which "ideologically barren" student organizations will be entangled in the electoral politics of their parent parties, while more radical and ideologically driven groups will remain under the state's magnifying glass.

Jean-Thomas Martelli's account stiches together the two methodological approaches of this special issue. Building on ethnographic and archival evidence, he engages with student political competition in Jawaharlal Nehru University (JNU) - one of the most politically vibrant campuses in India. He is critical about academic works on student politics depicting university campuses as epitomes of resistance or as sites doomed to reproduce wider socio-political realities. Martelli focuses on the process of formation of political attitudes among students and shows how they adopt dissonant political views in the context of intense and organized representational competition, in which sets of distinctive yet inter-breeding political idioms are mobilized. Through examining how rivalries between student organizations enabled the diffusion of minoritarian politics around queer, Hindu nationalist, Dalit and environmental issues. Martelli argues that "political spillovers" and "ideological cross-fertilization" can be understood as key processes behind the formation of dissonant political views among students. This serves as an explanation of how and why Hindu right groups adopt liberal and even left leaning rhetoric, and how and why Dalit and queer agendas have mainstreamed in JNU campus. Hence, Martelli portrays the university campus not only as a socially 
constructed space that is instrumental in fostering value-oriented political capital, but also as a field where innovators and early adopters of novel and hybridized political idioms are nurtured.

51 The next article returns to Bangladesh. Most recent ethnographic evidence depicts its student politics as being largely violent, masculine, factional, pragmatic and closely related to political parties (Andersen 2013; Suykens and Islam 2015; Suykens 2018; Kuttig 2019). Mascha Schulz's engagement with student politics in Shahjalal University of Science and Technology campus in Sylhet complements these accounts by showing that aside from evident factional realpolitik, ideological commitments also play a significant and complex role in the everyday conduct of student politics. More specifically, she explores how ideology is expressed through symbols flaunted on August 15-Bangladesh's national mourning day-which commemorates the killing of Sheikh Mujibur Rahman, the charismatic leader of Awami League that spearheaded the country's independence movement. Schulz reflects on the ambivalence of these commemorations, which are both ideologically charged and grounded in pragmatic politics: through them different political groups negotiate power relations, while the ruling party re-enforces its dominance. This leads Schulz to argue that ideology is simultaneously relevant and irrelevant to the conduct of student politics in Bangladesh.

Leah Koskimaki's article takes us to the often-overlooked India's Himalayan states through following the footsteps of two incipient upper caste student leaders in Uttarakhand's Nainital. The article explores the everyday strategies mobilized by student leaders to fashion for themselves a "regional charisma." Contradicting the Weberian notion of charisma as an exceptional inborn quality, she conceptualizes charisma as a characteristic that is built, cultivated and locally/regionally grounded. Koskimaki shows how student leaders in Nainital constructed their regional charisma through various means, by drawing on caste affiliations and political genealogies of Indian freedom fighters, by referring to pahari (hill) identity, simplicity and moral rectitude, and also by repeatedly demonstrating knowledge of the place. She gives a picture of student politics in Uttarakhand as being different from mainland India, less entangled in muscle politics and shaped in the image of youth innocence, selflessness and sacrifice. Student politics in this hill city is largely embedded and concerned with local aspirations and less aligned to national-scale issues and party politics.

Reflecting on the centrality of moral values in structuring political mobilization (Blom and Jaoul 2008), Kristina Garalyte's article shows the emerging tensions between the Dalit movement's ethics and divergent individual moralities among the Scheduled Caste (SC) students at Jawaharlal Nehru University. She presents a case study of a debate between two SC students, in which they argue over the moral demand of the Dalit movement to "pay back to society," and over their differing social mobility imaginaries. The identity of SC students appears to be strongly shaped by the ethical idea of the Dalit movement; nevertheless, there are differences of opinion regarding what constitutes the legitimate means of "paying back to society." Her underlying assumption is that different experiences lead to different moral positioning, thus creating symbolic boundaries among students. Garalyte argues that on the JNU campus, political mobilization coincides with moral socialization, and that in the context of student politics, morality and ideology are intertwined. 

peripheral significance for the conduct of student political activism in South Asia. Javid's account concurs with this assessment by indicating that student politics in modern day Pakistan lack ideological cleavages and identifiable ideologies (except for a few more radically inclined smaller groups). This is also partly corroborated by Koskimaki (2020) and Schulz's (2020) contributions. The latter argues that commemoration events on a Bangladeshi university campus, though being ideological at their core, are also "a privileged site for renegotiation of power relations and factional affiliations." Yet four ethnographic contributions demonstrate that ideological and value-based student activism pertain not merely to the glorious past of the student movements during the various independence movements in South Asia (Christiansen 2020; Gautier 2020; Garalyte 2020; Martelli 2020). These authors show that political idioms and values emerge as a core compass of present-day students' political fashioning. They matter more when students compete over various social issues, when they commemorate landmark historical events, when they frame their identities and self-present as charismatic. The articles presented in this issue of SAMAJ do not essentialize ideological commitments, but instead problematize them by showing that ideologies are not merely reproduced but are also appropriated, negotiated and contested. practices of student politics in South Asia. From a regional perspective, new contributions on Nepal, Sri Lanka and Maldives would further enrich our understanding of generational communities. Additional emphasis on the way sacrificial students-cum-militants renegotiate their selves when entering mainstream parliamentary party politics could be derived from the post-civil war Nepali case (Ramirez 2002; Lecompte-Tilouine 2006; Zharkevich 2009; Snellinger 2010; Hirslund 2012, 2018). Emphasis on borderland and ethnic-based forms of student activism in South Asia, in particular in Pakistan's Baluchistan, Sindh and Azad Kashmir (Nelson 2011; Javid 2020) could complement this approach. For instance, scholarship on India's North Eastern states (Bora 1992; Sinha 1995; Baruah 2002; Deka 2013) could benefit from exploring perspectives from within these groups. The complex interaction between communal agendas at the center, everyday political practices of constituents and the proliferation of ethno-religious student movements (Ahmad 2009) should receive urgent attention as majoritarianism triumphs in many regions of South Asia. Unfortunately, glimpses into student politics from organizations such as Islami Jamiate Tuleba (the student wing of Jama'at-e Islami) or the Akhil Bharatiya Vidyarthi Parishad (ABVP is the student wing of the Rashtriya Swayamsevak Sangh) are found only in passing mentions as part of authoritative accounts on their paternal (or fraternal) organizations in Pakistan (Gayer 2007; Iqtidar 2011) and India (Jaffrelot 1996; Hansen 1999). Future research agendas on student politics need to better understand how such politics functions in private institutions, since this educational model is becoming the new normal in South Asia.

56 As part of this endeavor, further attention on how politics in private education and training centers mold representations of masculinity among educated youth is timely (Ray 2019). Such attention can be further facilitated by moving beyond the exclusive study of organized politics, which tends to obfuscate non-partisan expressions of the political. Such broadening scope shall include political coordination and self-

South Asia Multidisciplinary Academic Journal, 22 | 2019 
expressions online, which is permitted by the diffusion and mass-use of social media, affordable smartphones and data packs (Agrawal 2018; Tenhunen 2018; Doron and Jeffrey 2013). With more and more student activism turning into "clicktivism" (Pathania 2013) on platforms that are increasingly targeted by political parties and socalled trolls, analyses could aim at comprehending how more voluntary and virtual generational communities, particularly among marginalized groups, emerge (Zaslavsky 2019). Last but not least, the complex question of "what happens after" student politics should not be avoided. In South Asia at large, we do not know whether students' engagements with politics make a durable predictor for life-long civic participation, or whether they merely constitute a fleeting life-stage-ultimately engendering minimal longstanding biographical consequences for student leaders, cadres and bystanders. As relatively few student activists enter full-time politics (Offerlé 1996), ethnographies ought to dive into the moral and strategic adjustments that both disengagement and professionalization engender. Trajectories of democratic participation in South Asia can be then fully uncovered in a diachronic fashion, by following agents' self-making after their student years as they renegotiate their political credentials away from the fold of the generational community.

\section{BIBLIOGRAPHY}

Abramson, Paul, and Ronald Inglehart. 1995. Value Change in Global Perspective. Ann Arbor: University of Michigan Press.

Agrawal, Ravi. 2018. India Connected: How the Smartphone Is Transforming the World's Largest Democracy. Oxford; New York: Oxford University Press.

Ahluwalia, Sagar. 1972. Youth in Revolt. New Delhi: Young Asia Publications.

Ahmad, Irfan. 2009. Islamism and Democracy in India: The Transformation of Jamaat-e-Islami. Princeton, NJ: Princeton University Press.

Allen, Joseph L. 1993. "Power and Political Community." The Annual of the Society of Christian Ethics 13:3-20.

Altbach, Philip. 1967. “Student Politics.” Transition (28):25.

Altbach, Philip. 1968. “Student Politics and Higher Education in India." Daedalus 97(1):254-73.

Altbach, Philip. 1969. Turmoil and Transition: Higher Education and Student Politics In India. Mumbai: Basic Books.

Altbach, Philip. 1970a. "India and the World University Crisis." Pp. 21-49 in The Student Revolution, edited by P. Altbach. Mumbai: Lalvani Publishing House.

Altbach, Philip. 1970b. The Student Revolution; A Global Analysis. Mumbai: Lalvani Publishing House. Altbach, Philip. 2006. "Student Politics: Activism and Culture." Pp. 341-2 in International Handbook of Higher Education, edited by J. J. F. Forest and P. Altbach. Dordrecht: Springer Netherlands. 
Altbach, Philip. 2014. "Student Political Activism." Pp. 247-60 in International Higher Education: An Encyclopedia, edited by P. Altbach. Abingdon, Oxon; New York: Routledge.

Amundsen , Inge. 2013. "Dynasty or Democracy? Party Politics in Bangladesh.” Chr. Michelsen Institute 12(6):1-4.

Andersen, Morten Koch. 2014. "The Politics of Politics: Youth Mobilization, Aspirations and the Threat of Violence at Dhaka University." PhD dissertation, Department of Social Science, Roskilde Universitet.

Andersen, Morten Koch. 2016. “Time-Use, Activism and the Making of Future." South Asia: Journal of South Asian Studies 39(2):415-29.

Appadurai, Arjun, V. Rao, and M. Walton. 2004. "The Capacity to Aspire: Culture and the Terms of Recognition." Pp. 59-84 in Culture and Public Action. Paolo Alto: Stanford University Press.

Aries, Elizabeth, and Maynard Seider. 2005. "The Interactive Relationship Between Class Identity and the College Experience: The Case of Lower Income Students." Qualitative Sociology 28(4):41943.

Arild, Ruud. 2010. “To Create a Crowd: Student Leaders in Dhaka." Pp. 70-95 in Power and Influence in India: Bosses, Lords and Captains, edited by P. Pamela and R. Arild. London: Routledge.

Arnett, Jeffrey. 1994. “Sensation Seeking: A New Conceptualization and a New Scale." Personality and Individual Differences 16(2):289-96.

Arnett, Jeffrey Jensen. 1998. "Learning to Stand Alone: The Contemporary American Transition to Adulthood in Cultural and Historical Context." Human Development 41(5-6):295-315.

Arnett, Jeffrey Jensen. 2001. "Conceptions of the Transition to Adulthood: Perspectives from Adolescence through Midlife." Journal of Adult Development 8(2):133-43.

Arnett, Jeffrey Jensen, and Susan Taber. 1994. “Adolescence Terminable and Interminable: When Does Adolescence End?" Journal of Youth and Adolescence 23(5):517-37.

Aronson, Pamela. 2008. “The Markers and Meanings of Growing Up: Contemporary Young Women's Transition from Adolescence to Adulthood." Gender \& Society 22(1):56-82.

Banerjee, Mukulika. 2008. "Democracy, Sacred and Everyday: An Ethnographic Case from India." Pp. 63-96 in Democracy: Anthropological Approaches, edited by J. Paley. Santa Fe: School for Advanced Research Press.

Banerjee, Sumanta. 1984. India's Simmering Revolution: The Naxalite Uprising. London: Totowa: Zed Books.

Barber, Benjamin R. 1998. A Place for Us: How to Make Society Civil and Democracy Strong. New York: Hill and Wang.

Baruah, Apurba K., ed. 2002. Student Power in North-East India: Understanding Student Movements. New Delhi: Regency Publications.

Baruah, Sanjib. 2014. “Routine Emergencies: India's Armed Forces Special Powers Act.” Pp. 189211 in Civil Wars in South Asia: State, Sovereignty, Development. New Delhi: SAGE Publications India Private Ltd.

Bayat, Asef. 2010. Life as Politics: How Ordinary People Change the Middle East. Amsterdam: Amsterdam University Press.

Bayat, Asef. 2017. Revolution without Revolutionaries: Making Sense of the Arab Spring. Stanford, California: Stanford University Press. 
Becker, Howard. 1963. Outsiders: Studies in the Sociology of Deviance. New York: Free Press Glencoe. Bert, Suykens, and Islam Aynul. 2015. The Distribution of Political Violence in Bangladesh (2002-2013). Ghent: Conflict Research Group.

Beyerlein, Kraig, and Kelly Bergstrand. 2013. "Biographical Availability.” Pp. 137-8 in The WileyBlackwell Encyclopedia of Social and Political Movements, edited by D. A. Snow, D. Della Porta, B. Klandermans, and D. McAdam. Oxford, UK: Blackwell Publishing Ltd.

Beyerlein, Kraig, and John Hipp. 2006. “A Two-Stage Model for a Two-Stage Process: How Biographical Availability Matters for Social Movement Mobilization.” Mobilization: An International Quarterly 11(3):299-320.

Bjorn, Alm. 2010. “Creating Followers, Gaining Patrons: Leadership Strategies in a Tamil Nadu Village." Pp. 1-19 in Power and Influence in India: Bosses, Lords and Captains, edited by P. Price and A. Ruud. London: Routledge.

Blom, Amélie, and Nicolas Jaoul. 2008. "Introduction. The Moral and Affectual Dimension of Collective Action in South Asia." SAMAJ: South Asia Multidisciplinary Academic Journal 2 (2008). Retrieved April 15, 2020 (https://journals.openedition.org/samaj/1912?lang=fr).

Bok, Derek Curtis. 2010. The Politics of Happiness: What Government Can Learn from the New Research on Well-Being. Princeton: Princeton University Press.

Bora, Shiela. 1992. Student Revolution in Assam, 1917-1947: A Historical Survey. New Delhi: Mittal Publications.

Bourdieu, Pierre. 2007. Sketch for a Self-analysis. Cambridge: Polity.

Brubaker, Rogers. 2004. Ethnicity Without Groups. Cambridge, MA: Harvard University Press.

Bulmer, Martin. 1986. The Chicago School of Sociology: Institutionalization, Diversity, and the Rise of Sociological Research. Chicago: University of Chicago Press.

Burawoy, Michael. 1976. "Consciousness and Contradiction: A Study of Student Protest in Zambia.” The British Journal of Sociology 27(1):78.

Carlevan, Romain. 2018. "Dynasties and Democracy in Contemporary India: An Empirical Study (1952-2015)." PhD dissertation, Department of Asian and International Studies, City University of Hong Kong.

Chakravarti, Sudeep. 2009. Red Sun: Travels in Naxalite Country. New Delhi: Penguin Books India. Chandra, Kanchan, ed. 2016. Democratic Dynasties: State, Party, and Family in Contemporary Indian Politics. Cambridge UK: Cambridge University Press.

Chandra, Kanchan, and Wamiq Umaira. 2011. “India's Democratic Dynasties.” Seminar 622:12-55. Chopra, Rohit. 2006. "Global Primordialities: Virtual Identity Politics in Online Hindutva and Online Dalit Discourse." New Media \& Society 8(2):187-206.

Chopra, Suneet. 1978. "Political Consciousness of the Student Movement in India." Social Scientist 6(10):53.

Christiansen, Samantha. 2020. “A Campus in Context: East Pakistan's 'Mass Upsurge' at a Local, Regional, and International Scales." SAMAJ: South Asia Multidisciplinary Academic Journal 22.

Cohen, Albert Kircidel. 1971. Delinquent Boys; the Culture of the Gang,. New York: Free Press (Macmillan). 
Cohen, Stanley, ed. 1982. The Manufacture of News. Social Problems, Deviance and the Mass Media. London: Constable.

Coleman, James S. 1988. "Social Capital in the Creation of Human Capital." American Journal of Sociology 94:95-120.

Cormack, Margaret. 1961. She Who Rides a Peacock: Indian Students and Social Change. New York: Praeger.

Crone, Mathilde R., Elke Zeijl, and Sijmen A. Reijneveld. 2016. "When Do Parents and Child Health Professionals Agree on Child's Psychosocial Problems? Cross-Sectional Study on Parent-Child Health Professional Dyads." BMC Psychiatry 16(1):151.

Crossley, Nick. 2008. "Social Networks and Student Activism: On the Politicising Effect of Campus Connections." The Sociological Review 56(1):18-38.

Dalton, Russell J. 1977. "Was There A Revolution? A Note on Generational Versus Life Cycle Explanations of Value Differences.” Comparative Political Studies 9(4):459-74.

De Souza, Rohan. 2004. "Some Reflections on Democracy and JNUSU." Pp. 25-8 in 30 Years in Defence of Progressive Democratic and Secular Culture: JNUSU Office Bearers Document, edited by the Jawaharlal Nehru University Students' Union. New Delhi: Alumni Association of Jawaharlal Nehru University (AAJ).

DeFronzo, James, and Jungyun Gill. 2019. Social Problems and Social Movements. Lanham: Rowman \& Littlefield.

Deka, Kaustubh. 2013. From Movements to Accords and Beyond: The Critical Role of Student Organizations in the Formation and Performance of Identity in Assam. Occasional Paper Series No. 9. Nehru Memorial Museum and Library (NMML): Teen Murti.

Deka, Kaustubh. 2015. Youth Activism and Democratic Politics in India's Northeast: 2014 Election in Perspective. Policy Report. 14. New Delhi: The Hindu Centre for Politics and Public Policy. Retrieved April 15, 2020 (https://www.thehinducentre.com/publications/policy-report/ article8029081.ece).

Deshpande, Satish. 2013. "Caste and Castelessness: Towards a Biography of the 'General Category." Economic and Political Weekly 48(15):32-9.

Deshpande, Satish. 2016. "The Public University after Rohith-Kanhaiya." Economic and Political Weekly 51(11):7-8.

Di Bona, Joseph. 1966. “Indiscipline and Student Leadership in an Indian University.” Comparative Education Review 10(2):306-19.

Doron, Assa, and Robin Jeffrey. 2013. The Great Indian Phone Book: How the Cheap Cell Phone Changes Business, Politics, and Daily Life. Cambridge, MA: Harvard University Press.

Dubey, Priyanka. 2017. "Student Days; The Age of ABVP." Caravan 9(10):1-40.

Durham, Deborah. 2004. "Disappearing Youth: Youth as a Social Shifter in Botswana." American Ethnologist 31(4):589-605.

Ehrkamp, Patricia, and Malene H. Jacobsen. 2015. “Citizenship.” Pp. 152-64 in The Wiley Blackwell Companion to Political Geography, edited by J. Agnew, V. Mamadouh, A. J. Secor, and J. Sharp. Chichester, UK: John Wiley \& Sons, Ltd.

Erikson, Erik H. 1980. Identity and the Life Cycle. New York: Norton. 
Etzioni, Amitai. 2014. “Community.” Pp. 1-14 in The Encyclopedia of Political Thought, edited by M. T. Gibbons, E. Ellis, D. Coole, and K. Ferguson. Chichester, UK: John Wiley \& Sons, Ltd.

Fendrich, James M. 1974. “Activists Ten Years Later: A Test of Generational Unit Continuity.” Journal of Social Issues 30(3):95-118.

Fernandez, Marilyn. 2018. The New Frontier: Merit vs. Caste in the Indian IT Sector. Oxford: Oxford University Press.

Fillieule, Olivier, ed. 2005. Le Désengagement Militant. Paris: Belin.

Fillieule, Olivier. 2009. “Conséquences Biographiques de l'engagement.” Pp. 131-9 in Dictionnaire des mouvements sociaux, Références. Sociétés en mouvement, edited by O. Fillieule, L. Mathieu, and C. Péchu. Paris: Presses de la Fondation nationale des sciences politiques.

Fillieule, Olivier. 2013. "Political Socialization and Social Movements." Pp. 524-31 in The WileyBlackwell Encyclopedia of Social and Political Movements, edited by D. A. Snow, D. Della Porta, and B. Klandermans. Malden, MA: Wiley.

Fillieule, Olivier, and Erik Neveu. 2019. Activists Forever? Long-Term Impacts of Political Activism. Cambridge: Cambridge University Press.

Forrester, Duncan B. 1966. “The Madras Anti-Hindi Agitation, 1965: Political Protest and Its Effects on Language Policy in India." Pacific Affairs 39(1/2):19-36.

Fournier, Bernard, and Raymond Hudon. 2012. Engagements citoyens et politiques de jeunes: bilan et expériences au Canada et en Europe. Sainte-Foy, Québec: Presses de l'Université Laval.

Fraser, Nancy. 1990. "Rethinking the Public Sphere: A Contribution to the Critique of Actually Existing Democracy." Social Text (25/26):56.

French, Patrick. 2011. India: A Portrait. New York: Alfred A. Knopf.

Gambetta, Diego, and Steffen Hertog. 2016. Engineers of Jihad: The Curious Connection between Violent Extremism and Education. Princeton: Princeton University Press.

Gamini, Samaranayake. 2015. "Changing University Student Politics in Sri Lanka: From Norm Oriented to Value Oriented Student Movements." Social Affairs 1(3):23-32.

Gangrade, K. D., and M. Sinha. 1971. Inter-Generational Conflict in India. Mumbai: Nachiketa Publications.

Garalyte, Kristina. 2020. "Symbolic Boundaries and Moral Demands of Dalit Student Activism." SAMAJ: South Asia Multidisciplinary Academic Journal 22.

Gautier, Laurence. 2020. “Crisis of the 'Nehruvian Consensus' or Pluralisation of Indian Politics? Aligarh Muslim University and the Demand for Minority Status." SAMAJ: South Asia Multidisciplinary Academic Journal 22.

Gayer, Laurent. 2007. “Guns, Slums, and 'Yellow Devils': A Genealogy of Urban Conflicts in Karachi, Pakistan.” Modern Asian Studies 41(3):515-44.

Gieryn, Thomas F. 1983. "Boundary-Work and the Demarcation of Science from Non-Science: Strains and Interests in Professional Ideologies of Scientists." American Sociological Review 48(6): 781.

Giugni, Marco G. 2007. "Personal and Biographical Consequences." Pp. 489-507 in The Blackwell Companion to Social Movements, edited by D. A. Snow, S. A. Soule, and H. Kriesi. Oxford, UK: Blackwell Publishing Ltd. 
Granfield, Robert. 1991. "Making It by Faking It: Working-Class Students in an Elite Academic Environment." Journal of Contemporary Ethnography 20(3):331-51.

Guha, Ranajit, ed. 1997. A Subaltern Studies Reader, 1986-1995. Minneapolis: University of Minnesota Press.

Gusfield, Joseph R. 1970. Protest, Reform, and Revolt: A Reader in Social Movements. New York: Wiley. Häkli, Jouni, and Kirsi Pauliina Kallio. 2018. "On Becoming Political: The Political in Subjectivity." Subjectivity 11(1):57-73.

Hall, G. Stanley. [1904] 1972. Adolescence Its Psychology and Its Relations to Physiology, Anthropology, Sociology Sex, Crime, Religion and Education, Vol. I. New York: D Appleton \& Company.

Hansen, Thomas Blom. 1999. The Saffron Wave: Democracy and Hindu Nationalism in Modern India. Princeton: Princeton University Press.

Hansen, Thomas Blom. 2005. "Sovereigns Beyond the State: On Legality and Public Authority in India." Pp. 109-44 in Religion, Violence and Political Mobilisation in South Asia, edited by K. Ravinder. New Delhi: Sage Publications.

Hazary, Subas Chandra. 1987. Student Politics in India. New Delhi: Ashish Publishing House. Henry, Nikhila. 2018. The Ferment: Youth Unrest in India. New Delhi: Macmillan.

Henry, Odile, and Mathieu Ferry. 2017. "When Cracking the JEE Is Not Enough: Processes of Elimination and Differentiation, From Entry to Placement, in the Indian Institutes of Technology (IITs)." SAMAJ: South Asia Multidisciplinary Academic Journal 15/2017. Retrieved on April 15,2020 (https://journals.openedition.org/samaj/4291).

Heuser, Ryan, and Long Le-khak. 2012. "A Quantitative Literary History of 2,958 NineteenthCentury British Novels: The Semantic Cohort Method." Pamphlets of the Stanford Lab Series, No. 4. Stanford, CA: Stanford Lab.

Hirslund, Dan V. 2018. "Utopias of Youth: Politics of Class in Maoist Post-Revolutionary Mobilisation." Identities 25(2):140-57.

Hirslund, Dan Vesalainen. 2012. "Sacrificing Youth: Maoist Cadres and Political Activism in PostWar Nepal." PhD dissertation. Department of Anthropology, University of Copenhagen.

Inglehart, Ronald. [1977] 2006. The Silent Revolution: Changing Values and Political Styles among Western Publics. Princeton, N.J: Princeton University Press.

Inglehart, Ronald. 2007. "Postmaterialist Values and the Shift from Survival to Self-Expression Values." Pp. 223-39 in The Oxford Handbook of Political Behavior, edited by R. Dalton and H. Klingemann. Oxford: Oxford University Press.

Inglehart, Ronald F. 2008. “Changing Values among Western Publics from 1970 to 2006." West European Politics 31(1-2):130-46.

Iqtidar, Humeira. 2011. Secularizing Islamists? Jama'at-e-Islami and Jama'at-Ud-Da'wa in Urban Pakistan. Chicago: University of Chicago Press.

Jaffrelot, Christophe. 1996. The Hindu Nationalist Movement and Indian Politics: 1925 to the 1990s. London: Hurst.

Jaffrelot, Christophe, and Peter van der Veer. 2008. Patterns of Middle Class Consumption in India and China. New Delhi: Sage Publications Private Limited. 
Javid, Hassan. 2020. "Patronage, Populism, and Protest: Student Politics in Pakistani Punjab." SAMAJ: South Asia Multidisciplinary Academic Journal 22.

Jeffrey, Craig. 2008. "Kicking Away the Ladder: Student Politics and the Making of an Indian Middle Class." Environment and Planning D: Society and Space 26(3):517-36.

Jeffrey, Craig. 2009. "Fixing Futures: Educated Unemployment through a North Indian Lens." Comparative Studies in Society and History 51(1):182-211.

Jeffrey, Craig. 2010. Timepass: Youth, Class, and the Politics of Waiting in India. Stanford, CA: Stanford University Press.

Jeffrey, Craig. 2013. "Geographies of Children and Youth III: Alchemists of the Revolution?" Progress in Human Geography 37(1):145-52.

Jeffrey, Craig, and Jane Dyson. 2014. “'I Serve Therefore I Am': Youth and Generative Politics in India." Comparative Studies in Society and History 56(4):967-94.

Jeffrey, Craig, and Stephen Young. 2012. "Waiting for Change: Youth, Caste and Politics in India." Economy and Society 41(4):638-61.

Jeffrey, Craig, and Stephen Young. 2014. "Jugād: Youth and Enterprise in India." Annals of the Association of American Geographers 104(1):182-95.

Jenkins, J. Craig. 1983. "Resource Mobilization Theory and the Study of Social Movements." Annual Review of Sociology 9:527-53.

Jennings, M. Kent, and Richard G. Niemi. 1981. Generations and Politics: A Panel Study of Young Adults and Their Parents. Princeton, N.J: Princeton University Press.

Jennings, M. Kent, Laura Stoker, and Jake Bowers. 2009. "Politics across Generations: Family Transmission Reexamined." The Journal of Politics 71(3):782-99.

Kabir, Arif Haq, and Janinka Greenwood. 2017. "Neoliberalism, Violence and Student Resistance in the Higher Education Sector in Bangladesh." Society and Culture in South Asia 3(1):68-91.

Kakar, Sudhir. 1970. Conflict and Choice: Indian Youth in a Changing Society. New Delhi: Somaiya Publications.

Karl, Mannheim. [1928] 1956. “The Problem of Generations." Pp. 226-322 in Essays on the Sociology of Knowledge, edited by K. Kecskementi. London: Routledge.

Kaviraj, Sudipta. 2005. "On the Enchantment of the State: Indian Thought on the Role of the State in the Narrative of Modernity." European Journal of Sociology 46(2):263-96.

Kemmis, Daniel. 1992. Community and the Politics of Place. Norman: University of Oklahoma Press.

Kent Carrasco, Daniel. 2016. “Jayaprakash Narayan and Lok Niti: Socialism, Gandhism and Political Cultures of Protest in XX Century India." PhD Dissertation, Department of Philosophy, King's College London.

Ketchley, Neil, and Michael Biggs. 2017. "The Educational Contexts of Islamist Activism: Elite Students and Religious Institutions in Egypt.” Mobilization: An International Quarterly 22(1):57-76.

Klandermans, Bert. 1984. "Mobilization and Participation: Social-Psychological Expansions of Resource Mobilization Theory." American Sociological Review 49(5):583.

Klandermans, Bert, Jojanneke van der Toorn, and Jacquelien van Stekelenburg. 2008.

"Embeddedness and Identity: How Immigrants Turn Grievances into Action." American Sociological Review 73(6):992-1012. 
Klawiter, Maren. 2008. The Biopolitics of Breast Cancer: Changing Cultures of Disease and Activism. Minneapolis: University of Minnesota Press.

Koskimaki, Leah. 2020. "Regional Charisma: The Making of a Student Leader in a Himalayan Hill Town." SAMAJ: South Asia Multidisciplinary Academic Journal 22.

Krishna, Anirudh. 2002. Active Social Capital: Tracing the Roots of Development and Democracy. New York: Columbia University Press.

Krishna, Anirudh. 2007. "How Does Social Capital Grow? A Seven-Year Study of Villages in India." The Journal of Politics 69(4):941-56.

Krishna, Anirudh. 2011. "Local Politics." Pp.299-313 in The Oxford Companion to Politics in India, edited by N. G. Jayal and P. B. Mehta. New Delhi: Oxford University Press.

Kukathas, Chandran. 1996. "Liberalism, Communitarianism, and Political Community." Social Philosophy and Policy 13(1):80-104.

Kumar, Sanjay, ed. 2019. Youth in India: Aspirations, Attitudes, Anxieties. Abingdon, Oxon, New York: Routledge.

Kumar, Satendra. 2012. "Ethnography of Youth Politics: Leaders, Brokers and Morality in a Provincial University in Western Uttar Pradesh." History and Sociology of South Asia 6(1):41-70.

Kusenbach, Margarethe. 2006. "Patterns of Neighboring: Practicing Community in the Parochial Realm.” Symbolic Interaction 29(3):279-306.

Kuttig, Julian. 2019. “Urban Political Machines and Student Politics in 'Middle' Bangladesh: Violent Party Labor in Rajshahi City.” Critical Asian Studies 51(3):403-18.

Lama-Rewal, Stéphanie Tawa. 2018. Les Avatars de La Participation: Formes et Ambiguïtés de La Démocratie Participative En Inde. Vulaines-sur-Seine: Éditions du Croquant.

Lamont, Michèle, and Virág Molnár. 2002. "The Study of Boundaries in the Social Sciences.” Annual Review of Sociology 28(1):167-95.

Lave, Jean, Paul Duguid, Nadine Fernandez, and Erik Axel. 1992. "Coming of Age in Birmingham: Cultural Studies and Conceptions of Subjectivity." Annual Review of Anthropology 21(1):257-82.

Lave, Jean, and Etienne Wenger. 1991. Situated Learning: Legitimate Peripheral Participation. Cambridge, New York: Cambridge University Press.

Lecomte-Tilouine, Marie. 2006a. “'Kill One, He Becomes One Hundred': Martyrdom as Generative Sacrifice in the Nepal People's War.” Social Analysis 50(1):51-72.

Lecomte-Tilouine, Marie. 2006b. “'Kill One, He Becomes One Hundred': Martyrdom as Generative Sacrifice in the Nepal People's War." Social Analysis: The International Journal of Social and Cultural Practice 50(1):51-72.

Lehmann, Wolfgang. 2009. "Becoming Middle Class: How Working-Class University Students Draw and Transgress Moral Class Boundaries." Sociology 43(4):631-47.

Levesque, Julien. 2020. "From Student Organizations to Ethnic Parties: The Consolidation of Sindhi Nationalism during One Unit." Pp. 220-59 in Pakistan: Alternative Imaginings of the NationState, edited by J. Schaflechner and C. Österheld. Karachi: Oxford University Press.

Liechty, Mark. 2003. Suitably Modern: Making Middle-Class Culture in a New Consumer Society. Princeton, N.J: Princeton University Press. 
Loader, Brian D., Ariadne Vromen, and Michael A. Xenos. 2014. "The Networked Young Citizen: Social Media, Political Participation and Civic Engagement." Information, Communication \& Society 17(2):143-50.

Luescher-Mamashela, Thierry. 2015. "Theorising Student Activism in and beyond the 20th Century: The Contribution of Philip G. Altbach." Pp. 33-49 in Student Engagement in Europe: Society, Higher Education and Student Governance, edited by M. Klemenčič, S. Bergan, and R. Primožič. Brussels: Council of Europe Publications.

Lukose, Ritty. 2005. “Consuming Globalization: Youth and Gender in Kerala, India.” Journal of Social History 38(4):915-35.

Lukose, Ritty A. 2009. Liberalization's Children: Gender, Youth, and Consumer Citizenship in Globalizing India. Durham: Duke University Press.

Malik, Yogendra K., and Jesse F. Marquette. 1974. "Changing Social Values of College Students in the Punjab." Asian Survey 14(9):795-806.

Martelli, Jean-Thomas. 2017. "Waiting for the Liberal Indian Enfant Terrible." Asia Dialogue. Retrieved October 3, 2020 (https://theasiadialogue.com/2017/07/14/waiting-for-the-liberalenfant-terrible/).

Martelli, Jean-Thomas. 2019a. "Pamphlet Repository for Changing Activism." Website for the Exhibition "Memories of Change." Retrieved October 3, 2020 (topol.hypotheses.org).

Martelli, Jean-Thomas. 2019b. "The Politics of Our Selves: Left Self-Fashioning and the Production of Representative Claims in Everyday Indian Campus Politics." Modern Asian Studies Forthcoming: $1-100$.

Martelli, Jean-Thomas. 2020. "The Spillovers of Competition: Value-Based Activism and Political Cross-Fertilization in an Indian Campus." SAMAJ: South Asia Multidisciplinary Academic Journal 22.

Martelli, Jean-Thomas, and Barış Arı. 2018. "From One Participant Cohort to Another: Surveying Inter-Generational Political Incubation in an Indian University." India Review 17(3):263-300.

Martelli, Jean-Thomas, and Khaliq Parkar. 2018. "Diversity, Democracy, and Dissent: A Study on Student Politics in JNU." Economic and Political Weekly 53(11):1-30.

McAdam, Doug. 1986. "Recruitment to High-Risk Activism: The Case of Freedom Summer." American Journal of Sociology 92(1):64-90.

McAdam, Doug. 1990. Freedom Summer. New York: Oxford University Press.

McAdam, Doug. 1999. Political Process and the Development of Black Insurgency, 1930-1970. Chicago: University of Chicago Press.

McAdam, Doug. 2000. "Culture and Social Movements." Pp. 253-68 in Culture and Politics, edited by L. Crothers and C. Lockhart. New York: Palgrave Macmillan US.

McDonald, Kevin. 2004. “Oneself as Another: From Social Movement to Experience Movement." Current Sociology 52(4):575-93.

Meyer, John W., and Richard Rubinson. 1972. "Structural Determinants of Student Political Activity: A Comparative Interpretation." Sociology of Education 45(1):23.

Michelutti, Lucia. 2008. The Vernacularisation of Democracy: Politics, Caste, and Religion in India. New Delhi: Routledge. 
Michelutti, Lucia, Ashraf Hoque, Nicolas Martin, David Picherit, Paul Rollier, Arild Engelsen Ruud, and Clarinda Still, eds. 2019. Mafia Raj: The Rule of Bosses in South Asia. Stanford, CA: Stanford University Press.

Ministry of Human Resource Development. 2019. All India Survey on Higher Education 2018-2019. New Delhi: MHRD.

Ministry of Human Resource Development, MHRD. 2006. Lyngdoh Committee Report. Committee Recommendations. New Delhi.

Muxel, Anne, ed. 2011. La Politique Au Fil de l'âge. Paris: Presses de la Fondation nationale des sciences politiques.

Muxel, Anne. 2018. Politiquement Jeune. La Tour d'Aigues [Paris]: Éditions de l'Aube ; Fondation Jean-Jaurès.

Nasr, Seyyed Vali Reza. 1992. "Students, Islam, and Politics: Islami Jami'at-I Tulaba in Pakistan." Middle East Journal 46(1):59-76.

Naudet, Jules. 2011. “L'expérience de La Mobilité Sociale-Plaidoyer Pour Une Approche Par Le Discours." Bulletin of Sociological Methodology/Bulletin de Méthodologie Sociologique 112(1):43-62.

Naudet, Jules. 2018. Stepping into the Elite: Trajectories of Social Achievement in India, France, and the United States. New Delhi: Oxford University Press.

Nelson, Matthew J. 2011. "Embracing the Ummah: Student Politics beyond State Power in Pakistan.” Modern Asian Studies 45(3):565-96.

Nisbett, Nicholas. 2007. "Friendship, Consumption, Morality: Practising Identity, Negotiating Hierarchy in Middle-Class Bangalore." Journal of the Royal Anthropological Institute 13(4):935-50.

Offerlé, Michel. 1996. “Entrées en politique." Politix. Revue des sciences sociales du politique 9(35):35.

Oinas, Elina, Henri Onodera, and Leena Suurpää. 2018. "Evasive Youth, Oblique Politics." Pp. 1-20 in What Politics? Youth and Political Engagement in Africa, Youth in a Globalizing World, edited by E. Oinas, H. Onodera, and L. Suurpää. Leiden, Boston: Brill.

Oldenburg, Ray. 1999. The Great Good Place: Cafés, Coffee Shops, Bookstores, Bars, Hair Salons, and Other Hangouts at the Heart of a Community. New York: Marlowe.

Oommen, T. K. 1974. "Student Politics in India: The Case of Delhi University.” Asian Survey 14(9): 777-94.

Osella, Caroline, and Filippo Osella. 1998. "Friendship and Flirting: Micro-Politics in Kerala, South India." The Journal of the Royal Anthropological Institute 4(2):189-206.

Pandey, Alok, and Chandrashekar Srinivasan. 2019. "In BHU Face-Saver, Transfer for Muslim Sanskrit Professor Facing Protests.” NDTV, October 12. Retrieved April 15, 2020 (https:// www.ndtv.com/india-news/muslim-sanskrit-professor-who-was-shut-out-by-bhu-studentsresigns-2146442).

Pandey, Gyanendra. 2005. "Notions of Community: Popular and Subaltern." Postcolonial Studies 8(4):409-19.

Paracha, Nadeem. 2019. “Who's Afraid of Student Activism.” Dawn, November 24. Retrieved April 15, 2020 (https://www.dawn.com/news/1518579).

Partha Chatterjee. 2012. “The Movement Against Politics.” Cultural Critique 81:117. 
Party Documents. 2013. "Resolution on the Tasks and Orientation of the Student-youth Movement." Ninth Congress of the CPI(ML): Liberation, May. Retrieved April 15, 2020 (http:// cpiml.org/party-documents/resolution-on-student-youth-movement/5).

Pasquali, Paul. 2010. “Les déplacés de l'ouverture sociale': Sociologie d'une expérimentation scolaire." Actes de la recherche en sciences sociales 183(3):86.

Pathania, Gaurav. 2013. "Campus Space in the Age of Clicktivism: Exploring JNU Students Union Elections.” Mainstream Weekly, September 28. Retrieved April 15, 2020 http:// mainstreamweekly.net/article4471.html).

Pathania, Gaurav J. 2018. The University as a Site of Resistance: Identity and Student Politics. New Delhi: Oxford University Press.

Paul, Subin, and David O. Dowling. 2018. "Digital Archiving as Social Protest: Dalit Camera and the Mobilization of India's “Untouchables.” Digital Journalism 6(9):1239-54.

Percheron, Annick. 1991. “La Mémoire Des Générations : La Guerre d'Algérie-Mai 68.” Pp. 39-57 in SOFRES: État de l'opinion, edited by O. Duhamel and J. Jaffré. Paris: Seuil.

Percheron, Annick. 1993. La Socialisation Politique. Malakoff: Armand Colin.

Pilcher, Jane. 1994. “Mannheim's Sociology of Generations: An Undervalued Legacy.” The British Journal of Sociology 45(3):481.

Polletta, Francesca. 1999. “"Free Spaces' in Collective Action.” Theory and Society 28(1):1-38.

Poonam, Snigdha. 2018. Dreamers: How Young Indians Are Changing the World. Gurgaon, Haryana: Penguin/Viking.

della Porta, Donatella. 2019. "Deconstructing Generations in Movements: Introduction." American Behavioral Scientist 63(10):1407-26.

Price, Pamela, and Arild Ruud. 2012. Power and Influence in India: Bosses, Lords and Captains. London: Routledge.

Pushkar. 2017. “It Makes Little Sense to Blame Students for India's Growing Loan Default Problem.” The Wire, July 31. Retrieved April 15, 2020 https://thewire.in/education/seriousindias-student-loan-default-problem).

Putnam, Robert D. 1995. “Bowling Alone: America's Declining Social Capital.” Journal of Democracy 6(1):65-78.

Raghavan, Srinath. 2013. 1971: A Global History of the Creation of Bangladesh. Cambridge, MA: Harvard University Press.

Rai, Pronoy. 2019. "Seasonal Masculinities: Seasonal Labor Migration and Masculinities in Rural Western India." Gender, Place \& Culture 27(2):1-20.

Rajimwale, Anil. 2001. History of Student Movement in India: Origins and Development (1920-1947). Delhi: Manak Publications.

Raka, Ray. 1998. "Women's Movements and Political Fields: A Comparison of Two Indian Cities." Social Problems 45(1):21-36.

Raka, Ray. 2019. “The Masculinity of Subaltern Youth: Jobs, Anxiety, and Political Possibility.” Pp. 1-18 in ICAS-IEG-CSH Workshop: Youth Politics and Projects of Self-Making in the Global South. New Delhi: Conference Proceedings. 
Ramirez, Philippe. 2002. “La guerre populaire au Népal : d'où viennent les maoïstes ?” Hérodote 107(4):47.

Reay, Diane, Gill Crozier, and John Clayton. 2009. “'Strangers in Paradise'?: Working-Class Students in Elite Universities.” Sociology 43(6):1103-21.

Reddy, M. M. 1947. The Student Movement in India. Kolkata: KSR Acharya.

Rege, M. P. 1971. "Inter-Generational Conflict: A Theoretical Perspective.” Pp. 37-59 in Intergenerational Conflict in India, edited by M. Sinha and K. D. Gangrade. Mumbai: Nachiketa Publications.

Robehmed, Alexandra. 2015. "Developing Apps, Developing Jordan? ICT Startup Entrepreneurs as Subjects of International Development in Amman's ‘Silicon Wadi."” PhD dissertation, Graduate School of Arts and Sciences, Georgetown University.

Rosanvallon, Pierre. 1998. “Le Nouveau Travail de Le Représentation.” Esprit 240(2):40-59.

Rose, Nikolas. 2000. “Community, Citizenship, and the Third Way." American Behavioral Scientist 43(9):1395-1411.

Ross, Aileen. 1969. Student Unrest in India: A Comparative Approach. Montreal: McGill-Queen's PressMQUP.

Rudolph, Lloyd I., and Susanne Hoeber Rudolph. 1987. In Pursuit of Lakshmi: The Political Economy of the Indian State. Chicago: University of Chicago Press.

Rukmini, S. 2014. “India Elects Its Oldest Ever Parliament.” The Hindu, May 26. Retrieved April 15, 2020 (https://www.thehindu.com/opinion/lead/india-elects-its-oldest-ever-parliament/ article6020532.ece).

Ruud, Arild. 2001. “Talking Dirty about Politics: A View from a Bengali Village.” Pp. 115-35 in The Everyday State and Society in Modern India, edited by C. Fuller and B. Véronique. New Delhi: Social Science Press.

Ruud, Arild Engelsen. 2014. “The Political Bully in Bangladesh.” Pp. 303-25 in Patronage as Politics in South Asia, edited by A. Piliavsky. Cambridge: Cambridge University Press.

Savory Fuller, Rebecca. 2018. “Embodying 'New India' through Remixed Global Performance: Flash Mobs Redefined in Contemporary Urban India, 2003-15.” PhD Dissertation, Centre of Drama, University of Exeter.

Schafer, Tyler. 2019. “Community." Pp. 545-55 in The Wiley-Blackwell Encyclopedia of Urban and Regional Studies, Wiley Blackwell Encyclopedias of Environment and Society, edited by A. M. Orum, M. García, and D. R. Judd. Hoboken: Wiley-Blackwell.

Schutz, Alfred. 1976. “The Stranger.” Pp. 91-105 in Collected papers II: Studies in Social Theory, edited by A. Schutz. New York: Springer.

Schulz, Mascha. 2020. "Performing the Party. National Holiday Events and Politics at a Public University Campus in Bangladesh.” SAMAJ: South Asia Multidisciplinary Academic Journal 22.

Schwarz, Christoph H., and Anika Oettler. 2017. "Political Temporalities of Youth." Middle EastTopics \& Arguments 9:5-14.

Settersten Jr., Richard A., Frank F. Furstenberg, and Rubén G. Rumbaut. 2005. On the Frontier of Adulthood: Theory, Research, and Public Policy. Chicago: University of Chicago Press.

Shachar, Ayelet. 2003. "Children of a Lesser State: Sustaining Global Inequality through Citizenship Laws." Nomos 44:345-97. 
Shah, Alpa. 2006. "The Labour of Love: Seasonal Migration from Jharkhand to the Brick Kilns of Other States in India." Contributions to Indian Sociology 40(1):91-118.

Shah, Alpa. 2018. Nightmarch: Among India's Revolutionary Guerrillas. London: Hurst \& Company.

Shah, Ghanshyam. 2004. Social Movements in India: A Review of the Literature. 2nd and enlarged ed. New Delhi, Thousand Oaks: Sage Publications.

Sharma, Amogh. 2019."Internet Hindus and the Rise of Post-Truth Politics in India," October 4, Workshop, Mediated Campaigns and Unmediated Politics in Millennial India at the Centre de Sciences Humaines (CSH). New Delhi: Workshop Proceedings.

Sharma, S. L. 1971. "Social Background and Outlook of Student Activists: Its Bearing on Disquiet Campus." in The Indian Youth: Emerging Problems and Issues, edited by P. Mehta. Mumbai: Somaiya Publications.

Shils, Edward. 1968. "Indian Students: Rather Sadhus than Philistines." Pp. 38-52 in Turmoil and Transition: Higher Education and Students Politics in India, edited by P. G. Altbach. Mumbai: Lalvani Publishing House.

Shils, Edward. 1969. “The Academic Profession in India.” Minerva 7(3):345-72.

Singh, A. K. 1968. "Academic Politics and Student Unrest: The Case of Ranchi University." Pp. 204-32 in The Student Revolution: A Global Analysis, edited by P. Altbach. Bombay: Lalvani. Singh Bal, Hartosh. 2019. “The Takeover: How the RSS Is Infiltrating India's Intellectual Spaces.” Caravan, 22-32. Retrieved April 15, 2020 (https://caravanmagazine.in/reportage/how-rssinfiltrating-india-intellectual-spaces).

Singh, Mohinder, and Rajarshi Dasgupta. 2019. "Exceptionalising Democratic Dissent: A Study of the JNU Event and Its Representations." Postcolonial Studies 22(1):59-78.

Singhvi, Laxmi M. 1972. Youth Unrest: Conflict of Generations. New Delhi: National Publishing House. Sinha, A. C. 1995. Youth Movement in North-East India. Gangtok: Har-Anand Publications.

Sinha, Durganand. 1975. "Dimensions of Student Agitations in India." Journal of Social and Economic Studies 3(2):112-29.

Siraj, Nasrin, and Ellen Bal. 2017. “'Hunger Has Brought Us into This Jungle': Understanding Mobility and Immobility of Bengali Immigrants in the Chittagong Hills of Bangladesh." Social Identities 23(4):396-412.

Siroux, Jean-Louis. 2008. "La dépolitisation du discours au sein des rapports annuels de l'Organisation mondiale du commerce." Mots. Les langages du politique nº 88(3):13-23.

Sitapati, Vinay. 2011. "What Anna Hazare's Movement and India's New Middle Classes Say about Each Other." Economic and Political Weekly 46(30):39-44.

Snellinger, Amanda Thérèse. 2006. "Commitment as an Analytic: Reflections on Nepali Student Activists? Protracted Struggle.” PoLAR: Political and Legal Anthropology Review 29(2):351-64.

Snellinger, Amanda Thérèse. 2010. "Transfiguration of the Political: Nepali Student Activism and the Politics of Acculturation." PhD Dissertation, Department of Anthropology, Cornell University. Snellinger, Amanda Thérèse. 2018. Making New Nepal: From Student Activism to Mainstream Politics. Seattle: University of Washington Press.

Staeheli, Lynn A. 2008. "Citizenship and the Problem of Community." Political Geography 27(1):521. 
Steinberg, Laurence. 2010. “A Dual Systems Model of Adolescent Risk-Taking.” Developmental Psychobiology 52(3):216-24.

Subramanian, Ajantha. 2019. “Meritocracy and Democracy.” Public Culture 31(2):275-88.

Sukumar, Narayana. 2016. “'Red Sun in the Blue Sky': Rohith Vemula's Utopian Republic.” Social Change 46(3):451-7.

Suykens, Bert. 2018. “'A Hundred Per Cent Good Man Cannot Do Politics': Violent Self-Sacrifice, Student Authority, and Party-State Integration in Bangladesh." Modern Asian Studies 52(3):883916.

Taylor, Verta. 1989. “Social Movement Continuity: The Women's Movement in Abeyance." American Sociological Review 54(5):761-75.

Taylor, Verta, and Alison Dahl Crossley. 2013. “Abeyance.” Pp. 210-16 in The Wiley-Blackwell Encyclopedia of Social and Political Movements, edited by D. A. Snow, D. Della Porta, B. Klandermans, and D. McAdam. Oxford, UK: Blackwell Publishing Ltd.

Teltumbde, Anand. 2019. “The University as Passivity? The Role of Students' Political Activism.” Pp. 127-48 in The Idea of the University: Histories and Contexts, edited by D. Bhattacharya. New Delhi: Routledge India.

Tenhunen, Sirpa. 2018. A Village Goes Mobile: Telephony, Mediation, and Social Change in Rural India. New York: Oxford University Press.

Thakur, Arvind Kumar. 2019. "New Media and the Dalit Counter-Public Sphere.” Television \& New Media 21(2):1-16.

The Education Commission. 2019. The 2030 Youth Skills Scorecard. Global Business Coalition for Education. Retrieved April 15, 2020 (https://gbc-education.org/project/2030-skills-scorecard).

Times of India Reporter. 2019. “Anti-CAA Stir: Students at Jamia Millia Islamia Form Protest Panel.” Times of India, December 19. Retrieved April 15, 2020 (https:// timesofindia.indiatimes.com/city/delhi/anti-caa-stir-students-at-jamia-millia-islamia-formprotest-panel/articleshow/72879419.cms).

Townsend, Nicolas W., and K.V. Hansen. 2001. “Community, Expression Of.” Pp. 471-80 in International Encyclopedia of the Social and Behavioral Sciences, edited by N. Smelser and P. Baltes. Amsterdam; New York: Elsevier.

Tucker, Robert C., ed. 1978. The Marx-Engels Reader. 2d ed. New York: Norton.

Turner, Edith. 2012. Communitas. New York: Palgrave Macmillan US.

Turner, Victor. 1969. The Ritual Process Structure and Anti-Structure. New York: Aldine de Gruyter.

Turner, Victor. 1974. "Liminal to Liminoid, in Play, Flow, and Ritual: An Essay in Comparative Symbology." Rice Institute Pamphlet-Rice University Studies 60(3).

UNESCO Institute for Statistics. 2018. "School Enrollment Ratio in Tertiary Education in South Asia.” Retrieved May 3, 2020 (https://Data.Worldbank.Org/Indicator/SE.TER.ENRR? Locations $=1 A-1 W-8 S-E U-B 8-Z G-Z Q)$.

United Nations and Department of Economic and Social Affairs. 2018. World Youth Report: Youth and the 2030 Agenda for Sustainable Development. Retrieved May 3, 2020 (https://www.un.org/ development/desa/youth/world-youth-report/wyr2018.html).

Van Dyke, Nella, and Marc Dixon. 2013. “Activist Human Capital: Skills Acquisition and the Development of Commitment to Social Movement Activism." Mobilization 18(2):197-212. 
Van Dyke, Nella, McAdam, and Brenda Wilhelm. 2000. "Gendered Outcomes: Gender Differences in the Biographical Consequences of Activism." Mobilization 5(2):161-77.

Verkaaik, Oskar. 2004. Migrants and Militants: Fun and Urban Violence in Pakistan. Princeton, NJ: Princeton University Press.

Vidyarthi, Lalita Prasad. 1976. Students Unrest in Chotanagpur 1969-70. New Delhi: Punthi Pustak. Warner, Michael. 2002. Publics and Counterpublics. New York : Cambridge, MA: Zone Books. Weeraperuma, Susunaga. 2009. Sunil the Struggling Student. Marrakesh: M. Al Aafaq Al Maghribia Newspaper Publications.

Wellman, Barry, and Barry Leighton. 1979. "Networks, Neighborhoods, and Communities: Approaches to the Study of the Community Question." Urban Affairs Quarterly 14(3):363-90.

Whalen, Jack, and Richard Flacks. 1989. Beyond the Barricades: The Sixties Generation Grows Up. Philadelphia: Temple University Press.

Whittier, Nancy. 1997. "Political Generations, Micro-Cohorts, and the Transformation of Social Movements." American Sociological Review 62(5):760.

Wilkinson, Tom. 2020. "Student Politics in British India and Beyond: The Rise and Fragmentation of the All India Student Federation (AISF), 1936-1950." SAMAJ: South Asia Multidisciplinary Academic Journal 22.

Yadav, Yogendra. 1999. "Electoral Politics in the Time of Change: India's Third Electoral System, 1989-99." Economic and Political Weekly 34(34/35):2393-9.

Young, Stephen, Satendra Kumar, and Craig Jeffrey. 2017. "Beyond Improvisation? The Rise and Rise of Youth Entrepreneurs in North India." Transactions of the Institute of British Geographers 42(1):98-109.

Zald, Mayer N., and Roberta Ash. 1966. "Social Movement Organizations: Growth, Decay and Change." Social Forces 44(3):327.

Zaslavsky, Floriane. 2019. "Mouvements Sociaux et Internet En Inde : Stratégies de Visibilité Médiatique et d'intégration à l'espace Public." PhD Dissertation, Département of Sociologies, Ecole des hautes études en sciences sociales (EHESS).

Zhao, Dingxin. 1998. "Ecologies of Social Movements: Student Mobilization during the 1989 Prodemocracy Movement in Beijing." American Journal of Sociology 103(6):1493-529.

Zhao, Dingxin. 2004. The Power of Tiananmen: State-Society Relations and the 1989 Beijing Student Movement. Chicago : Bristol: University of Chicago Press.

Zharkevich, Ina. 2009. “A New Way of Being Young in Nepal: The Idea of Maoist Youth and Birth of a New Man.” Studies in Nepali History and Society 14 (1):67-105.

\section{NOTES}

1. Rohith Chakravarti Vemula was an Indian sociology research student at the University of Hyderabad. Repeatedly penalized by the administration and rival student groups for his involvement in Dalit student politics in campus, he committed suicide on January 17; 2016 (Henry 2018; Sukumar 2016).

2. South Asia is the world region with the largest number of youths, with nearly half of its 1.9 billion population below the age of 24 (Word Youth Report 2018). One fourth of South Asian 
children are on track to complete secondary education; this proportion is estimated to grow to nearly half of the children in the region by 2030 (GBCE Report 2019). South Asia's gross enrolment ratio in tertiary education is growing exponentially (from 7 percent in 1998 to 24 percent in 2018), but apart from Sub-Saharan Africa (9 percent), it still ranks below its world counterparts (37 percent). Important discrepancies exist within the region; Pakistan lags (9 percent) as compared to Maldives (31 percent), India (28 percent), Bangladesh (21 percent), Sri Lanka (20 percent), Bhutan (2018) and Nepa (12 percent) (UNESCO Institute for Statistics 2018). Similar discrepancies exist in terms of gender representation, even if nearly forty percent of the academic staff in South Asia is female. As an order of magnitude, one in eight males in Bangladesh has attained the equivalent of a bachelor's degree, and one in a hundred men in Pakistan has completed a PhD (UNESCO Institute for Statistics 2018).

3. Admittedly, biographical availability varies significantly according to students' social background; it depends also on the type of studies they are engaged in. In general, those from humble social backgrounds as well as those pursing private vocational courses tend to experience more financial constraints. This is evident as loans for higher education have grown exponentially in the past two decades (Pushkar 2017). However, due to the lack of available evidence, it is not entirely clear what kind of relationships exist between student debts and political participation in South Asia, as debts increase costs of political participation, but also increase one's economic grievances.

4. The establishment of JNU in 1969 as a flagship postgraduate university in the social sciences first reflected the ambitions of the socialist left at the center structured around the alliance between the Communist Party of India (CPI) and the Indian National Congress (INC). After the state of Emergency declared by Prime Minister Indira Gandhi (1975-1977), the Union reflected more clearly the regional domination of the Communist Party of India (Marxist) (CPI(M)) in West Bengal and Kerala (1977-2004). Finally, in the last decade, it has been promoting the student wing of the Communist Party of India (Marxist-Leninist) CPI(ML), a formerly anti-parliamentary Bihari-centric organization converted to electoral democracy in the early 1990 s.

5. During the Kiss of Love campaign, Kerala and Indian youth used social media platforms such as Facebook to spread images and videos of kissing performances in public. This was used as a way to protest against the moral policing spread by Hindu Right groups. The Pinjra Tod (Break the cage) protest was initiated by female students in various Delhi universities, demanding fewer constraining regulations in university student halls and the right to access safely maledominated public spaces. The Why Loiter campaign initiated by three feminist activists in Mumbai is attempting to reclaim public spaces for women. Advocating for leisurely and gender-blind access to the city, the Meet to Sleep staged performances defying sexual harassment threats by calling women to nap in public parks. Lastly, the Happy to Bleed campaign sought to challenge the prevalent menstrual taboos in India through flaunting sanitary pads in public spaces.

6. For instance, examples of such documents in India are: "Student Front: Policy And Tasks," adopted by the Central Committee of the CPI(M) (The Marxist January-March 2007), "Urban Perspective Plan 2004 of the CPI(Maoist)" (cf. Chakravarti 2009:322-48) and the "Resolution on The Tasks and Orientation of the Student-Youth Movement," adopted by the Ninth Congress of the CPI(ML) (Liberation May 2013).

7. Students usually maintain close relations of kinship with their families. However, individuals residing on campus tend to gain more autonomy vis-à-vis their guardians and childhood friends since their integration to their new educational setting is higher than those living outside university premises.

8. Because university spaces are inclusionary in scope-as they depend on the exclusion of noneligible members (Staeheli 2008) -they require what Gieryn (1983) calls boundary work, that is some demarcation between desirable and undesirable group attributes. Often, this perimeter is defined negatively through answering the question "who we are not" (Lamont and Molnár 2002) 
and might involve occurrences of social control (Etzioni 2014). Student collectives shall thus, at least superficially, abide by inclusive goals even if the actuality of the community is marked by internal divisions (Kukathas 1996). Such inclusive aspirations are generally associated with the sharing of ethical norms (Rose 2000), shared affectual relationships and a sense of mutual responsibility (Etzioni 2014).

9. For an example, c.f. the pamphlets part of the "Pamphlet Repository for Changing Activism" (PaRChA), an online platform created by Martelli (2019a). They are available here: www.topol.hypotheses.org/495 (accessed 9 December 2019).

10. In line with Bayat (2017:22), passive networks are understood as "instantaneous communications among atomized individuals that are established by the tacit recognition of their commonalities and that are mediated directly through the gaze in public space, or indirectly through mass media."

\section{INDEX}

Keywords: student politics, youth, university, generation, community

\section{AUTHORS}

\section{JEAN-THOMAS MARTELLI}

Centre de Sciences Humaines (CSH), Politics and Society Division, New Delhi

\section{KRISTINA GARALYTÉ}

Assistant Professor, Institute of Asian and Transcultural Studies at Vilnius University 